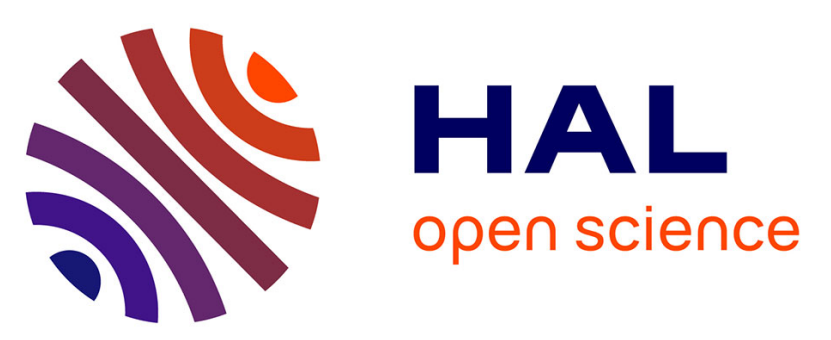

\title{
Evaluation and analysis of deep percolation losses of drip irrigated citrus crops under non-saline and saline conditions in a semi-arid area
}

Houda Nassah, Salah Er-Raki, Saïd Khabba, Younes Fakir, Fatima Raibi, Olivier Merlin, Bernard Mougenot

\section{To cite this version:}

Houda Nassah, Salah Er-Raki, Saïd Khabba, Younes Fakir, Fatima Raibi, et al.. Evaluation and analysis of deep percolation losses of drip irrigated citrus crops under non-saline and saline conditions in a semi-arid area. Biosystems Engineering, 2018, 165, pp.10-24. hal-01940007v2

\section{HAL Id: hal-01940007 \\ https://hal.science/hal-01940007v2}

Submitted on 24 Dec 2018

HAL is a multi-disciplinary open access archive for the deposit and dissemination of scientific research documents, whether they are published or not. The documents may come from teaching and research institutions in France or abroad, or from public or private research centers.
L'archive ouverte pluridisciplinaire HAL, est destinée au dépôt et à la diffusion de documents scientifiques de niveau recherche, publiés ou non, émanant des établissements d'enseignement et de recherche français ou étrangers, des laboratoires publics ou privés. 


\section{Evaluation and analysis of deep percolation losses of drip irrigated citrus 2crops under non-saline and saline conditions in a semi-arid area}

3

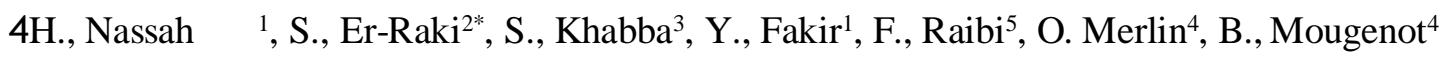
5

$6{ }^{1}$ GEOHYD, Département de Géologie, Faculté des Sciences Semlalia, Université Cadi Ayyad, 7Marrakech, Morocco

$8 \quad{ }^{2}$ LP2M2E, Département de Physique Appliquée, Faculté des Sciences et Techniques, Université Cadi 9Ayyad, Marrakech, Morocco

10 32LMME, Département de Physique, Faculté des Sciences Semlalia, Université Cadi Ayyad, 11Marrakech, Morocco

$12 \quad{ }^{4} \mathrm{CESBIO}$, Centre d'Etudes Spatiales de la Biosphère, Toulouse, France

13 5 CNESTEN, Centre National de l'Energie des Sciences et des Techniques Nucléaires, Morocco

$14 *$ Corresponding author address:

15Dr. Salah Er-Raki

16 LP2M2E, Département de physique, Faculté des Sciences et Techniques (FSTG), Cadi Ayyad 17University. Av. Abdelkarim Elkhattabi. B.P 549, 40000 Marrakech, Morocco

18 Tel: (+212) (0) 524433404 / Fax: (+212) (0) 524433170

19 Email: $\quad$ s.erraki@uca.ma/s.erraki@gmail.com 


\section{Abstract}

21In arid and semi-arid regions, irrigation management is important to avoid water loss by soil 22evaporation and deep percolation (DP). In this context, estimating the irrigation water demand 23has been investigated by many studies in the Haouz plain. However, DP losses beneath 24irrigated areas in the plain have not been quantified. To fill the gap, this study evaluated DP 25over two drip-irrigated citrus orchards (Agafay and Saada) using both water balance and 26direct fluxmeter measurement methods, and explored the simple FAO-56 approach to 27optimise irrigation in order to both avoid crop water stress and reduce DP losses in case of 28nonsaline and saline soils. The experimental measurements determined different terms of the 29 water balance by using an Eddy-Covariance system, fluxmeter, soil moisture sensors and a 30meteorological station. Using the water balance equation and fluxmeter measurements, results 31 showed that about $37 \%$ and $45 \%$ of supplied water was lost by DP in Saada and Agafay sites, 32respectively. The main cause of DP losses was the mismatch between irrigation and the real 33crop water requirement. For Agafay site, it was found that increased over-irrigation had the 34effect of reducing soil salinity by leaching salts.

35The applied FAO-56 model suggested an optimal irrigation scheduling by taking into account 36both rainfall and soil salinity. The recommended irrigations could save about $39 \%$ of supplied 37water in non-saline soil at Saada and from $30 \%$ to $47 \%$ in saline soil at Agafay.

38Key words: Saline soil; water balance; fluxmeter; FAO-56 approach; irrigation scheduling.

\section{Introduction}

40In the southern Mediterranean region, as in many arid and semi-arid regions of the world, 41water scarcity is one of the main factors limiting crop development, growth and yield 42(Kharrou et al., 2013). In this region, irrigation is a major component of water demand. It is 43 estimated that about $83 \%$ of available resources is dedicated to agriculture with an efficiency 44lower than 50\% (Chehbouni et al., 2008). In Morocco, this waste of water has several origins 45including leakage during water routing, but also a lack of irrigation efficiency in the field 46(Khabba et al., 2013; Belaqziz et al., 2014). Indeed, scheduling in timing and amount of 47irrigation is mostly determined according to the water availability so that the actual plant 48water needs are generally not taken into account. In addition, the traditional flooding systems 49are predominantly leading to significant water loss by soil evaporation and deep percolation 50(DP) (Kharrou et al., 2011). Currently, the Moroccan government has set up an ambitious 
51 program for irrigation conversion from flood to drip (PMV, 2013). However, the obtained 52results for DP are surprising as an inadequate use of the drip technique may lead to substantial 53water losses (Khabba et al., 2013). It has been shown that the DP losses for the drip irrigation 54sites are in the range 29-41\% of water input while they are relatively lower for flood 55irrigation, ranging from 26 to $31 \%$ (Khabba et al., 2013). Moreover, as the soil salinity may 56limits plant growth (Ayars et al., 2012), the farmers usually apply excessive irrigation to leach 57soil salinity out of root layer or root zone and hence avoid salinity stress (Visconti et al., 582012). In general, over-irrigation amounts are arbitrary and largely estimated. In our study 59 basin, this situation leads to an overexploitation of groundwater, with a level decreasing from 601 to $3 \mathrm{~m}$ year $^{-1}$ (Le Page et al., 2012; Boukhari et al., 2015).

61In order to preserve water resources, the rationalisation of irrigation water use is necessary. 62An accurate estimation of the water consumed by evapotranspiration (ET) and lost by DP 63would provide a basis for improving irrigation efficiency (Kharrou et al., 2013; Belaqziz et 64al., 2014; Xianwen et al., 2016).

65Regarding ET, crop coefficients and associated measurements have been reported in the 66literature and used to test, develop and calibrate a range of ET models (Allen et al., 2011; Er67Raki et al., 2013). DP is commonly assessed by the soil water balance equation when both ET 68and water supply irrigation and rainfall are available (Sammis et al., 1983). The method has 69been used under different irrigation techniques and for various crops (Vázquez et al., 2006; 70Wang et al., 2012). DP can also be measured by direct methods such as lysimeters (Allen et 71al., 1991; Kim et al., 2011; Duncan et al., 2016), or fluxmeters (Deurer et al., 2008; Gee et al, 722009). However, these methods are expensive (Upreti et al., 2015) and may disrupt flow, 73 causing errors in the measured drainage (Gee et al., 2009).

74Other indirect methods have also been used such as the hydraulic method (Qinbo et al., 2011; 75Allman et al., 2015), temperature measurements in the unsaturated zone (Constantz et al.,

762003; Landon et al., 2016), and geochemical tracers (Stonestrom et al., 2003; Stephens et al., 772006).

78In Morocco, citrus is one of the main components of agricultural systems (Boubker, 2004). 79Currently, it covers a total area of about 120,000 ha (MAPM, 2013), but it is in rapidly 80 expanding. However, in Morocco, the key physiological stages of this crop (from flowering to 81 maturation) coincide with the dry period (March-October). Thus, intensive irrigation is 82necessary for citrus development (E1 Hari et al., 2010). As far as we know such a study on the 83estimation of DP for citrus in Morocco conditions has never been performed before. 
84In this context, the objective of this study is twofold: 1) the evaluation and analysis of DP for 85 citrus orchards irrigated by drip system and grown under semi-arid conditions, and 2) the 86exploration of FAO-56 simple approach to optimise irrigation in order to both control crop 87 water stress and to reduce DP in the case of saline and non-saline soils. The analysis of DP 88 losses can potentially provide useful information for optimising citrus irrigation schedules 89 under non-saline and saline soil conditions. To our best knowledge it is the first time that the 90FAO-56 method has been tested for citrus under saline soil conditions.

\section{MATERIALS AND METHODS}

\subsection{Sites description}

93The study was conducted on two citrus orchards: Agafay and Saada (Figure 1). The Agafay 94site covers an area of 38 ha approximately $44 \mathrm{~km}$ southwest of Marrakech city (31 ${ }^{\circ} 29^{\prime}$ 9550.19"N, $\left.008^{\circ} 25^{\prime} 02^{\prime \prime W}\right)$. The field experiment was carried out from 2006 to 2013 in a 96mandarin orchard planted in July 2000. The trees were planted at a spacing of $4 \mathrm{~m}$ in rows and $976 \mathrm{~m}$ between rows, which is about $35 \%$ ground cover. The height of trees was about $3 \mathrm{~m}$ and 98the depth of the root zone around $0.6 \mathrm{~m}$. This depth was determined by making five pits near 99to the tree's root zone. The crop was maintained in over-irrigated conditions by drip irrigation: 100the irrigation frequency was almost every day without taking into account rainfall events. 101Moreover, the amount of water applied by the farmers during each irrigation event varied 102between 2 and $9 \mathrm{~mm}^{\text {day }}{ }^{-1}$ depending on climatic conditions. The Agafay site is divided into 103three sectors and irrigated within 24 hours at a rate varying from 28 to $60 \mathrm{~m}^{3} \mathrm{ha}^{-1}$. Note that 104irrigation is applied during rainfall events in order to leach the soil salinity from the root zone. 105 The soil type is homogeneous, with high sand and low clay contents (18\% clay, 32\% silt and $10650 \%$ sand). According to the pedo-transfer function of Wosten et al. (1997) the soil moisture

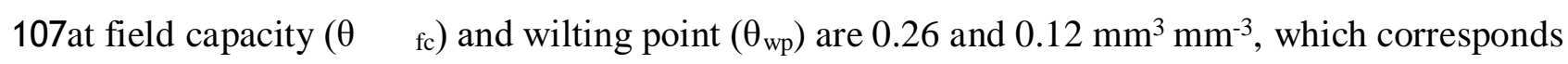
108 to 156 and $72 \mathrm{~mm}$ at the root zone at the experimental plot, respectively.

109The Saada site is located approximately $15 \mathrm{~km}$ west of Marrakech city (31 $37^{\prime} 36^{\prime \prime} \mathrm{N}$, $\left.11008^{\circ} 09^{\prime} 35^{\prime \prime} \mathrm{W}\right)$. It covers an area of 128 ha and is planted with 13 -year old mandarin trees; the 111 field experiment was conducted during 2004. The orange trees were placed at a spacing of 5 $112 \mathrm{~m}$ in rows and $3 \mathrm{~m}$ between rows, with $70 \%$ of the ground cover fraction. The average height 113 of the trees was about $3.15 \mathrm{~m}$ and the depth of the root zone was about $0.6 \mathrm{~m}$. The Saada 114citrus was maintained in over-irrigated conditions by daily irrigation varied from 2 to $5 \mathrm{~mm}$, 115depending on climatic conditions. The orchard is divided into several sectors, but all irrigated 116on the same day with a rate varying from 4 to $56 \mathrm{~m} \quad{ }^{3} \mathrm{ha}^{-1}$. The soils have high sand and low 
117clay contents (12\% clay, $38 \%$ silt, and $50 \%$ sand). More details about the two sites can be 118found in the studies by Er-Raki et al. (2009) and Er-Raki et al. (2012).

119For both sites, the farmers use the reference evapotranspiration (ET $\quad 0$ ) and the values of crop 120coefficients (Kc) for citrus provided in Table 12 in FAO-56 (Allen et al. 1998) for

121 determining the amount of irrigation as: irrigation $=\mathrm{Kc} * \mathrm{ET} \quad 0$. This can under or overestimate 122the irrigation water needs (Er-Raki et al. 2009). The drip irrigation system used in both sites is 123installed such that about $40 \%$ of the soil field is wetted corresponding to the irrigated part, 124 while $60 \%$ of the soil field remains as dry fraction which corresponds to the non-irrigated 125part. These areas are differentiated by their soil salinity degrees. In Agafay the soil has an 126electrical conductivity greater than $4 \mathrm{dS} \mathrm{m} \quad{ }^{-1}$ which qualifies as a highly saline soil based on 127Mathieu and Pieltain, (2003). By contrast, at the Saada orchard, the soil is considered non128saline (2 dS m $\left.\quad{ }^{-1}\right)$ (Sefiani et al., 2017).

129The climate of these areas is typically Mediterranean. It is characterised by low and irregular 130rainfall with an annual average of about $240 \mathrm{~mm}$ (Khabba et al., 2013). For the period 1972 1312012 , the average temperature is high in summer $\left(37^{\circ} \mathrm{C}\right)$ and low in winter $\left(5^{\circ} \mathrm{C}\right)$ (Kharrou et 132al., 2013). The rainy season is commonly from November to May with a maximum rainfall in 133November and February. The dry season is about five months, from May to September.

\subsection{Experimental Data}

135Meteorological parameters (rainfall, temperature, humidity, wind speed and direction and 136solar radiation) were measured by an automatic weather station installed at $2 \mathrm{~m}$ above over137irrigated clipped grass. Half-hourly measurements of these parameters are obtained by 138monitoring wind speed and direction using an anemometer A100R (R. M. Young Company, 139USA), air temperature and humidity using HMP45AC (Vaisala Oyj, Helsinki, Finland), 140incoming solar radiation using radiometer (Kipp \& Zonen CNR1, Netherlands) and rainfall 141using a rain gauge. Daily average values of meteorological data were calculated from the half 142hourly values in order to compute the daily ET $0\left(\mathrm{~mm} \mathrm{day}^{-1}\right)$, according to the FAO-56 143Penman-Monteith (Allen et al. 1998). The temporal evolution of daily ET ${ }_{0}$ (Figure 2) is 144typical for the semi-arid climate; low values in winter (1-2 mm), high values in summer (6-8 $145 \mathrm{~mm}$ ) and an annual average of about $1600 \mathrm{~mm}$. For Agafay orchard, the study concerns two 146years contrasting in their rainfall; 2007 and 2010 are considered as dry (148.3 mm) and rainy $147(342.6 \mathrm{~mm})$ years respectively.

148For the two sites Agafay and Saada, actual crop evapotranspiration (ET c_act) was measured by 149an eddy-covariance system. It consists of a 3D sonic anemometer (CSAT3, Campbell 
150Scientific Ltd.) and a fast response hygrometer (Campbell Scientific Inc., USA). Raw data 151 were sampled at a rate of $20 \mathrm{~Hz}$ and were recorded using data loggers (CR5000, Campbell 152Scientific Ltd). The size of both fields was large enough to meet the required fetch conditions 153for the eddy covariance system. The reliability of eddy covariance measurements in our 154studied sites was assessed by analysing the energy balance closure. Indeed, the obtained daily 155errors of this balance closure were generally less than $10 \%$ of available energy (Er-Raki et al., 1562012), which can be considered acceptable for the eddy covariance measurements over the 157tree-orchards (Ezzahar et al., 2007; Er-Raki et al., 2009; Er-Raki et al., 2012).

158In addition, soil moisture content was measured by 12 Time Domain Reflectometry sensors 159(TDR) (CS616, Campbell Scientific Ltd.). The TDR are installed in two different locations: 6 160in the non-irrigated part between the rows and 6 in irrigated part under tree canopies, at depths 161 of $5,10,20,30,40$, and $60 \mathrm{~cm}$, in order to measure the soil water content in different 162conditions. Measurements were taken at $1 \mathrm{~Hz}$, and $30 \mathrm{~min}$ averages stored data loggers 163(CR23X, Campbell Scientific Ltd.). Finally, a fluxmeter for direct measurement of DP was 164installed in the Agafay site at a depth of $80 \mathrm{~cm}$, beneath the root zone. Note that the fluxmeter 165 was not installed in the Saada site.

\subsection{Methodology}

167In our study, the deep percolation (DP) losses are defined as the water amounts flowing 168downwards below root zone. They are evaluated for the two studied sites by using the 169following soil water balance equation:

170

$$
\mathrm{DP}=\mathrm{P}+\mathrm{I}-\mathrm{ET}_{\mathrm{c} \_ \text {act }}-\mathrm{R}+\mathrm{CR} \pm \Delta \mathrm{W}
$$

171where DP, P, I, ET c_act, R and CR are deep percolation, precipitation, irrigation, actual crop 172evapotranspiration, runoff and capillary rise from water table respectively. These terms are all 173in $\mathrm{mm}$.

174Because the studied sites are both flat and the precipitations are not heavy, $\mathrm{R}$ is neglected in 175the water balance equation. Furthermore, as the water table is deep, depth varied from 15 to 17680 m (Boukhari et al., 2015), CR was considered to be zero.

$177 \Delta \mathrm{W}$ is the variation of soil water content in the root zone, defined as:

179 where $\mathrm{W}(\mathrm{t})$ is the water storage at time $\mathrm{t}$ in the root zone derived from the layer-wise soil

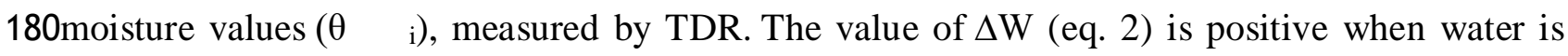


181added to the root zone; otherwise it is null or negative. At a given moment, water storage $\mathrm{W}$ 182(t) was computed from the values of $\theta \quad i(i=1, \ldots, 6)$ and the thickness of each layer $(\delta Z$, in $183 \mathrm{~mm})$ as:

184) $\mathrm{W}(\mathrm{t})=\Sigma^{6}\left(\phi \mathrm{Z} \quad \mathrm{i} * \theta_{\mathrm{i}}\right.$

185The relative deep percolation (DP $\quad \mathrm{R}$ ) as a percentage of the rate of irrigation or total water 186supply (irrigation and rainfall) is expressed respectively as follows:

$187 \quad \mathrm{DP}_{\mathrm{R}(\mathrm{I})}=(4)_{\mathrm{I}}^{\mathrm{DP}} * 100$

$188(\mathrm{D}) \mathrm{P}_{\mathrm{R}(\mathrm{I}+\mathrm{P})}=\frac{\mathrm{DPI}}{+\mathrm{P}} * 100$

189The calculated DP losses and the actual allocated amounts of drip irrigation are analysed at 190different time scales, especially for different growing stages: induction, flowering, fruit set, 191fruit drop, fruit growth, slowdown growth, maturation and harvest (El Hari, 1992). Note that 192this analysis was repeated for two years, 2007 and 2010, in Agafay and during 2004 in Saada 193site where the measurements are available. According to Bouazzama and Bahiri, (2008) and 194Domingo et al., (2007), one can note that high amount of irrigation is critical in fruit growth 195phase (June -October) to increase juice content and fruit size. The water stress during the fruit 196drop (May-June) decreases the number of fruit per tree, and this is why water availability in 197the soil in this period is important to reduce fruitlet fall (Bouazzama and Bahiri, 2008). Water 198stress can also influence fruit quality such as acidity in maturation stage, and reduce fruit 199numbers in flowering and fruit set phases (Lado et al., 2014; Käthner et al., 2017). Bellvert et 200al. (2016) has investigated the evaluation of water stress throughout different growing seasons 201 for several fruit tree species by using remotely-sensed indicators.

202Additionally, in order to assess the adequacy of the water supply at different growing stages, 203two indicators are used: depleted fraction (DF) and relative evapotranspiration (RET) indices 204(Eq. 4). DF represents the part of the water supply (I+P) that is consumed by the standard 205evapotranspiration (ETc), whereas RET allows assessing the occurrence of water deficits (Bos 206et al., 2005; Kharrou et al., 2013) defined as ratio of actual crop evapotranspiration (ET c_act) 207and (ETc):

208 andDF $=\frac{{ }^{\mathrm{ETc}}}{\mathrm{I}+\mathrm{P}} \quad \mathrm{RET}=\frac{\mathrm{ET}_{\mathrm{c} \_ \text {act }}}{\mathrm{ETc}}$ 
209The value of ETc is estimated using the FAO-56 simple approach (Allen et al., 1998) as the 210product of crop coefficient $(\mathrm{Kc})$ and ET $\quad 0$. The value of $\mathrm{Kc}$ for citrus is taken as 0.65 which is 211 the average value of the ratio between measured (ET c_act) by eddy covariance system and $\mathrm{ET}_{0}$. 212The obtained value of Kc is corroborated by the work of Er-Raki et al. (2009) when they 213 calibrated Kc values for citrus in the same region.

214For orange trees in arid and semi-arid areas, the critical value of DF is equal to 0.6 (Kharrou 215et al., 2013). Values of DF between 0.6 and 1.1 are assumed to have no significant effect on 216growth and yield.

217The RET index allows the occurrence of water deficits to be assessed (Roerink et al., 1997; 218Bos et al., 2005), with an acceptable range from 0.75 to 1 (Roerink et al., 1997). The critical 219 value of RET, which is taken to be 0.75 , corresponds to the economic threshold suggesting it 220 is reached when water stress has caused a $25 \%$ decrease in crop ET. This threshold can be 221 considered acceptable for irrigated agriculture if it does not lead to meaningful quality and 222quantity losses for farmers, whereas RET values that are lower than 0.75 are considered to 223involve a water stress that affects the agricultural development of the crop.

224In this study, the combined analysis of RET and DF indicators is used to identify how 225irrigation water management allows better crop development through the reduction of water 226stress (Kharrou et al., 2013).

227Thus, the diagram (RET, DF) allows the identification of four zones (Kharrou et al., 2013):

228Zone A: "farmer satisfaction", there is no water stress but irrigation is excessive,

229Zone B: “water manager's task", there is no water stress and the irrigation is adequate.

230Zone C: "risk", there are water stress and excessive irrigation.

231Zone D: "survival", water stress is induced by a wrong irrigation scheduling.

232In order to minimise DP, the FAO-56 approach is used to predict water requirement on a daily 233basis, by calculating the right amount of irrigation (I) without recording any water stress (Ks) 234and no losses by DP:

235 withl(IDP=ODP(i) $-\mathrm{P}(\mathrm{i})+\mathrm{ETc}(\mathrm{i})+\operatorname{Dr}(\mathrm{i}+(\mathrm{T}))$

236

$$
(\$) r(i)=\operatorname{Dr}(i-1)-P(i)-I(i)+E T c(i)+D p(i)
$$

237

$$
\text { (D) } r(i-1)=1000 *\left(\theta_{\mathrm{fc}}-\theta_{\mathrm{i}-1}\right) * \mathrm{Zr}
$$

238where $\mathrm{i}$ is the number of the day, $\theta \quad$ fc is the soil moisture content at field capacity $\left(\mathrm{m}^{3} \mathrm{~m}^{-3}\right), \theta_{\mathrm{i}-1}$ 239is the average soil moisture content in effective root zone $\left(\mathrm{m}^{3} \mathrm{~m}^{-3}\right)$, and $\mathrm{Zr}$ is the rooting depth 
240(m). Dr is the root zone depletion $(\mathrm{mm})$, which measures the difference between the total 241available water (TAW) and the actual available water. At field capacity, Dr is equal to zero 242and no water stress occurs (Eq. 10). When soil water is extracted by evapotranspiration, Dr 243increases until it exceeds the readily available water (RAW), and water stress will be induced 244(Eq. 11).

245Water stress coefficient (Ks) is expressed as (Allen et al., 1998):

$246 \operatorname{Dr}(\mathrm{i}) \leq \mathrm{RAW} \quad \mathrm{Ks}=1$

247Dr(i) $>$ RAW $\quad \mathrm{Ks}=\frac{\mathrm{TAW}-\mathrm{Dr}(\mathrm{i})}{\mathrm{TAW}-\mathrm{RAW}}$

$248 \mathrm{TAW} \in 12) 000 *\left(\theta_{\mathrm{fc}}-\theta_{\mathrm{wp}}\right) * \mathrm{Zr}$

$249 \operatorname{RAW}(\mathbf{P}) * \mathrm{TAW}$

250RAW and TAW are the readily available water and the total available water in the root zone $251(\mathrm{~mm}), \mathrm{p}$ is the depletion fraction which is equal to 0.5 for citrus orchards according to FAO25256 (Table 22, Allen et al., 1998). The TAW depends on the type of soil and the rooting depth 253(Kelly et al., 2010; Troy et al., 2013). Recently, Rosa et al., (2016) adjusted both TAW and 254RAW under saline conditions, for evapotranspiration partitioning of maize and sweet 255sorghum by applying the SIMDualKc approach.

256In the case of saline soil, such as the Agafay site, the leaching of salinity is essential for crop 257growth, development and yield (Visconti el al., 2012). Salt leaching requires adequate 258irrigation management, which is based on adding sufficient amounts of water beyond the crop 259water requirement for evapotranspiration and photosynthesis (Russo et al., 2009). Salt is 260 continually added to soils when the irrigation water salinity is higher than tolerable water 261 salinity value (Naidu et al., 1996; Yoseph and Jim, 2004) which varies for citrus from 0.75 to $2622.25 \mathrm{dS} \mathrm{m}^{-1}$ (Richards, 1954).

263Salts in the soil can reduce evapotranspiration by making soil water less "available" for plant 264root extraction (Allen et al., 1998). Salinity stress occurs when the salt concentration, 265evaluated by the electrical conductivity of the saturated-soil-paste extract (ECe), is higher 266than a given concentration threshold ECe threshold equal to $1.7 \mathrm{dS} \mathrm{m}^{-1}$. In this case we estimate 267salinity effect on evapotranspiration reduction by varying the soil electric conductivity from 268non-saline condition $\left(1.7 \mathrm{dS} \mathrm{m}^{-1}\right)$ to the high salinity $\left(10 \mathrm{dS} \mathrm{m}^{-1}\right)$, using the following 269formulae (Allen et al., 1998):

270When salinity stress occurs without water stress: Dr $<$ RAW 
272When soil water stress occurs in addition to salinity stress: Dr > RAW, the total stress (Ks tot) 273can be given by:

274 (16) $=\left(1-\frac{\mathrm{b}}{(\mathrm{Ky} * 100)} *(\mathrm{ECe}-\mathrm{ECe} \underset{\text { thershold }}{ })\right) *\left(\frac{\mathrm{TAW}-\mathrm{Dr}}{\mathrm{TAW}-\mathrm{RA})}\right)=\mathrm{Ks} \quad$ salinity $^{*} \mathrm{Ks}$

275 where $b$ is the percent yield reduction per unit increase in ECe (dS m $\left.{ }^{-1}\right)$, and Ky is the crop 276yield response factor being equal to 1.2 (Table 24, Allen et al., 1998).

277Citrus yields decrease by about $16 \%$ for each $1.0 \mathrm{dS} \mathrm{m} \quad{ }^{-1}$ over the ECe $e_{\text {threshold }}$ (Visconti el al., 2782012; FAO, 2003). The crop yield response factor was estimated according to Allen et al., 279(1998) as:

280

$$
1-\frac{\mathrm{Yr}}{\mathrm{Ym}}=\mathrm{Ky} *\left(1-{\left.\stackrel{\mathrm{ET}}{\mathrm{ET}_{-\mathrm{act}}}\right)}_{\mathrm{ETc}}\right.
$$

281

$$
\frac{\mathrm{Yr}}{\mathrm{Ym}}=1-(\mathrm{ECe}-\mathrm{ECe} \quad \text { thershold }) * \frac{\mathrm{b}}{100}
$$

282where $\mathrm{Yr}$ and $\mathrm{Ym}$ are the real and maximum yields $\left(\mathrm{kg}_{\mathrm{ga}}{ }^{-1}\right)$, respectively.

283The amount of water applied to wash out excess salts from the root zone is known as the 284leaching fraction (LF) (Plaut et al., 2013; FAO, 2003) and is commonly expressed using the 285following relationship (Ayers and Westcot, 1985):

286

$$
\mathrm{LF}=\frac{\mathrm{EC}_{\mathrm{iw}}}{5 \mathrm{EC}_{\text {thershold }}-\mathrm{EC}_{\mathrm{iw}}}
$$

287where EC iw is electrical conductivity of irrigation water $\left(\mathrm{dS} \mathrm{m} \mathrm{m}^{-1}\right)$.

\section{Results and Discussion}

\subsection{Evaluation of deep percolation (DP)}

\subsubsection{DP estimations}

291The value of DP is estimated by using water balance equation and fluxmeter. For the three 292years of this study, the annual ET c_act of citrus varied between 786.3 and $818 \mathrm{~mm}$ (Table 1). 293These values are similar to those reported for citrus orchards in the Haouz region (El Hari et 294al., 2010; Er-Raki et al., 2009, 2012). The difference between the annual ET c_act and rainfall 295was $490 \mathrm{~mm}$ year $\quad{ }^{-1}$ in Saada, $606 \mathrm{~mm}$ year-1 $^{-1}$ (2007) and $476 \mathrm{~mm}$ year-1 (2010) in Agafay 296(Table 1), with an average value of $524 \mathrm{~mm}$ year ${ }^{-1}$. This large gap makes irrigation very 
297critical for citrus growth and yield. However, using the water balance equation shows that the 298generated DP is very high, varying from $420.3,454.8$ to $708.6 \mathrm{~mm}$ year $\quad{ }^{-1}$ with an average of 299about $501 \mathrm{~mm}$ year $\quad{ }^{-1}$. These correspond to a $\mathrm{DP}_{\mathrm{R}(\mathrm{I}+\mathrm{P})}$ of $38.3,49.3$ and $46.3 \%$, with an average 300 value of $43 \%$.

301For more analysis of DP, we split the whole season into dry and wet periods. During the dry 302period, from June to October, about 59.8\% (2004) of irrigation was supplied in Saada, and $30362.8 \%$ (2007) and 67.3\% (2010) in Agafay. This generates respectively DP rates of about 304270.5, 240 and $417.5 \mathrm{~mm}$ dry-period $\quad{ }^{-1}$ as well as $\mathrm{DP}_{\mathrm{R}(\mathrm{I})}$ of 24.5\%, 34.7\% and 48.1\% (Table 2). 305During the wet period (November-May), the DP is relatively lower, recording an average of 306about $284 \mathrm{~mm}$, varying from 279.8, 216.7 to $355.5 \mathrm{~mm}$ wet-period ${ }^{-1}$, respectively, which 307represents DP R(I) values of about 46.1, 41.9 and 53.4\% (Table 2). According to those results, 308the annual DP values are about $500 \mathrm{~mm}$, corresponding to a DP $\quad \mathrm{R}(\mathrm{I}+\mathrm{P})$ of $43 \%$ and equivalent to 309almost double the habitual annual rainfall in the study region $(250 \mathrm{~mm})$.

310Several studies have estimated DP using water balance method in arid and semi-arid climates 311 by recording annual values of DP $\quad \mathrm{R}(\mathrm{I}+\mathrm{P})$ of about 11\% (García and Castel, 2007). Compared to 312this value, our two citrus orchards presented high DP values. This result does not affect the 313validity of the drip irrigation technique, which is known by its high efficiency ranged between 31480 and 90\% (Boman, 2002; Kelly et al., 2010). The observed losses are rather due to the 315 combined effects of an inadequate use of this technique and over-irrigation.

316Furthermore, direct measurement of DP was performed in 2010 by a fluxmeter installed just 317under the root zone in the Agafay orchard. Figure 3 shows the cumulative deep percolation 318measured by the fluxmeter (DP f) and the one calculated by water balance (DP). The evolution 319of the cumulative values of DP $\mathrm{f}$ is systematically lower than that of DP. However, the annual 320values of DP and $\mathrm{DP}_{\mathrm{f}}$ are similar; 708.6 and $638.9 \mathrm{~mm}$ for $\mathrm{DP}$ and $\mathrm{DP}_{\mathrm{f}}$ respectively. This 321difference could be explained by two reasons:

322-The scale used by both methods, since the water balance method calculates DP at 323parcel scale, while the fluxmeter measures DP at local scale;

324-The rainfall interception and runoff, which are not taken into account by the water 325balance equation (Eq.1). As reported by García and Castel, (2007), rainfall 326interception by trees is an important component of the water balance as it could 327 present $8 \%$ of rainfall.

328After a preliminary evaluation of deep percolation by using direct measurement (fluxmeter) 329 and soil water balance, the question left to address is to determine the most important factors 330such as soil water content, physiological and management responsible on the DP losses. 


\subsubsection{Soil water content and DP losses}

332The evaluation of DP losses is assessed by studying the variation of soil moisture content $(\theta \mathrm{i})$ 333in the root zone. For bare soil between the rows in the un-irrigated part of the field, Figure 4 334presents an example of the temporal evolution of the soil moisture in 60-80 cm depth (lower 335limit of root zone). In this part, which covers about $60 \%$ of the bare soil, the average soil 336 moisture in the root zone varies between the wilting point $\left(\theta \quad\right.$ wp $\left.=0.12 \mathrm{~mm}^{3} \mathrm{~mm}^{-3}\right)$ and the field

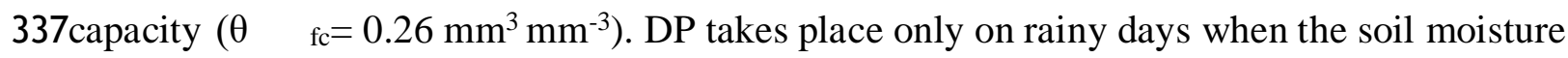
338exceeds $\theta \quad$ fc.

339For the irrigated part of the field along tree rows in Agafay and Saada sites, the soil moisture 340in 60-80 $\mathrm{cm}$ depth is frequently above $\theta \quad$ fc (Figure 5). Therefore, DP losses were occurring 341almost throughout both dry and wet periods due to the high frequency of irrigation events.

\subsubsection{DP as a function of growth stages}

343Knowing that some part of water supply can be used by the plant and other part can be lost by 344direct soil evaporation and/or by DP, it is crucial to estimate the amount of water lost by DP 345 which is the main objective of this present study. The supplied water is split into crop water 346use (ET c_act) and DP in each crop stage. Figure 6 illustrates an example of irrigation amount 347 according to the phenological phases. The results show that the higher irrigation values are 348recorded during fruit growth stage, occurring in summer. In this stage, irrigation were 552 349mm and $582.4 \mathrm{~mm}$ in 2007 and 2010 in Agafay and $239.7 \mathrm{~mm}$ in 2004 in Saada site, 350representing about $54.4 \%, 50.52 \%$ and $33.4 \%$ of annual irrigation. In descending order, the 351 irrigation rate of the other phases at Agafay $(2007,2010)$ and Saada (2004) are: $16.2 \%$, $35217.2 \%, 19.7 \%$ for fruit drop phase; $9.6 \%, 10.7 \%$, and $10.4 \%$ for maturation, $9.6 \%$, 9.9\%, $3539.7 \%$ for flowering and fruit set; $2.4 \%, 2.7 \%, 3.3 \%$ for induction; and 2\%, $1.5 \%, 2.9 \%$ for 354harvest.

355The higher values of DP losses which equal $200 \mathrm{~mm}$, with DP $\quad$ R(I) of about 35\%, are recorded 356during fruit growth stage (Figure 6). Though this is an important growth period and water 357demand is high (ET c_act $\approx 390 \mathrm{~mm}$ ), the irrigation in this stage is largely overdosed (about 560 $358 \mathrm{~mm})$. During the other phases, the DP quantities $(\mathrm{mm})$ are relatively lower, but still important 359by comparison to the irrigation amounts (Figure 7). This explains that a major part of supplied 360 water is lost by DP when the phenological activities and evapotranspiration are low.

\subsubsection{Evaluation of water supply adequacy}


362The evaluation of water supply adequacy by using the diagram RET-DF shows that all 363phenological phases are in zone A and B of Figure 8, which is consistent with the above 364findings (Figure 7):

365-Zone A includes the phases characterised by excess irrigation, recording a DF value 366less than 0.6. For Agafay, these phases are fruit growth, slowdown growth, maturation 367and harvest for 2007 and 2010 seasons. In Saada case, the phases were flowering, 368maturation and harvest. This results shows that the orange trees were largely over369irrigated. Consequently, these phases need removed to zone B.

370-Zone $\mathrm{B}$ includes the phases characterised by an adequate use of irrigation water, 371recording DF values between 0.6 and 1.1. These phases are induction, flowering, fruit 372set, and fruit drop for Agafay, and induction, fruit drop, fruit growth, slowdown 373growth and fruit set, for Saada.

374According to these results, the Saada site is characterised by more adequate use of irrigation 375during the majority of its growth stages than the Agafay site. This is expected since the 376Agafay site has a high level of soil salinity that needs more water for salt leaching and then 377more DP losses. This aspect is discussed further in the following section.

\subsection{Impact of rainfall and soil salinity on DP}

\subsubsection{Effects of rainfall on DP losses}

380To analyse the effective role of rainfall in citrus water supply and its impact on DP losses, we 381compare the data of Agafay recorded in the dry year $2007(148 \mathrm{~mm})$ and the rainy year 2010 $382(343 \mathrm{~mm})$. Despite the high rainfall in 2010, the supplied irrigation $(1188 \mathrm{~mm})$ was higher 383than $2007(1061 \mathrm{~mm})$. Consequently the DP losses are greater $(708.6 \mathrm{~mm})$ in 2010 than in 3842007 (454.8 mm) (Table 1). Even in the wet year of 2010 the drip irrigation alone exceeds the $385 \mathrm{ET}$ c_act by $31 \%$ (Figure 9).

386At a weekly scale, the farmers supplied irrigations in five weeks in 2007 and nine in 2010 387(examples giving in Table 3), although the rainfall amounts were adequate to fulfil crop water

388need (ET c act). Such behaviour attests to the inappropriate application of irrigation: the wrong 389 quantity is delivered at the wrong moment. Consequently, the DP reached high values, with $390 \mathrm{an}$ average of $34.6 \mathrm{~mm}$ week $\quad{ }^{-1}$ (Figure 9). The way irrigation is applied by the farmer was not 391appropriate for controlling DP losses.

\subsubsection{Impacts on DP of measures to control soil salinity}


393In Agafay site, the high soil salinity (about $4 \mathrm{dS} \mathrm{m} \quad{ }^{-1}$ ) could explain the applied over-irrigation. 394In this case, the irrigation water is used in excess for leaching soil salts in order to avoid root 395dieback and leaf loss of citrus (Sheng et al., 2002; Ayars et al., 2012). For Agafay orange, the 396irrigation water exceeds ET c_act by about 306.8 and $370.5 \mathrm{~mm}$ in dry and wet years, 397respectively. These DP amounts correspond to about 29 and $31 \%$ of irrigation water, 398respectively. However, Robert and Richard (1999) reported that only $17 \%$ irrigation excess is 399needed for salt leaching. Also Barnard et al., (2010) and Plaut et al. (2013) found that in sandy 400loam soil, similar to the Agafay site, $20 \%$ of irrigation excess is sufficient to leach salts from 401the root zone. This result shows that, in Agafay orchard, the applied water quantities are still 402higher than is needed to address the salinity issue.

\subsection{Irrigation water management to control DP losses and crop water stress}

404The optimisation of irrigation water scheduling, in time and quantity, was performed by using 405FAO-56 simple approach for the two orange sites in order to avoid both water stress and deep 406percolation (i.e. $\mathrm{Ks}=1$ and $\mathrm{DP}=0$ at all times). Based on the equation (7), the obtained results 407show that annual values of recommended irrigations without taking into account the salinity 408issue are 685 and $530 \mathrm{~mm}$ for Agafay (2007 and 2010) and $558 \mathrm{~mm}$ for Saada. By adding the 409amount of rainfall (149, 343 and $296 \mathrm{~mm}$, respectively), the total supplied coincides with the 410adequate citrus water requirement $\left(845 \mathrm{~mm}\right.$ year $\quad{ }^{-1}=\mathrm{Kc}^{*} \mathrm{ET}_{0}=0.65 * 1300 \mathrm{~mm}$ year $^{-1}$ ) 411(FAO, 2003; Er-Raki et al., 2009; El Hari et al., 2010). The recommended irrigation can then 412save approximately 39 and $45 \%$ of the irrigation in Saada and Agafay, respectively.

413As the Agafay site is under high soil salinity, it is of interest to quantify the effect of this 414parameter on the stress and on the amount of irrigation needed. The total stress (Ks tot) 415increases (Figure 10) when soil electrical conductivity exceeds the tolerable salinity threshold 416of citrus $\left(1.7 \mathrm{dS} \mathrm{m}^{-1}\right)$. In this case, the impact of salinity is remedied by adding an additional 417irrigation to the recommended amount. This supplemental irrigation is used for salinity 418leaching and not used by the crop, and then lost by DP. The question addressed is how much 419amount of water should be used as a leaching fraction (LF).

420Based on equation (18), when the soil electrical conductivity is $2.5 \mathrm{dS} \mathrm{m}{ }^{-1}$, the leaching $421 \mathrm{fraction}$ is $17 \%$ of water supply. This fraction equals an additional irrigation of about 116 and $42290 \mathrm{~mm}$ year $\quad{ }^{-1}$ for 2007 and 2010, respectively. By considering these amounts, the annual 423recommended irrigation needed to avoid water and salinity stress ranges between $766 \mathrm{~mm}$ 424(2007) and $624 \mathrm{~mm}(2010)$. 
425Taking into account the water and salinity stress and DP losses, the recommended irrigations 426in Saada and Agafay allowed us to plot all the growing phases in zone B with $\mathrm{DF}=1$. This is 427likely to ensure an effective irrigation strategy for optimising citrus irrigation schedules, while 428avoiding water stress and DP losses. The recommended irrigation can then save 429approximately 39 and $37 \%$ of the irrigation in Saada and Agafay, respectively. Saving 430irrigation water in such proportions is equivalent to save $3520 \mathrm{~m}^{3} \mathrm{ha}^{-1} \mathrm{year}^{-1}$ in Saada and $4312950 \mathrm{~m}^{3} \mathrm{ha}^{-1}$ year-1 $^{-1}$ (2007) to $5640 \mathrm{~m}^{3} \mathrm{ha}^{-1}$ year $^{-1}$ (2010) in Agafay. The average quantity of 432irrigation water that could be saved is about $4295 \mathrm{~m}^{3} \mathrm{ha}^{-1} \mathrm{year}^{-1}$. If we consider 6000 ha of 433citrus in the Haouz plain cultivated and irrigated in the same conditions of Agafay site, the 434overall saved amount of water would be $25.8 \quad 10 \quad{ }^{6} \mathrm{~m}^{3}$ year $^{-1}$.

\section{Conclusion}

436The paper investigates deep percolation (DP) in citrus orchards with drip irrigation under 437semi-arid climate and develops a method based on the FAO-56 model to define irrigation 438schemes and to optimise irrigation in non- saline and saline soil conditions.

439The results obtained show that, under the irrigation conditions of the study, the DP calculated 440 by the water balance equation is very high; varying from 420 to $709 \mathrm{~mm}$ year $\quad{ }^{-1}$ with a relative 441DP R(I) value of about 38.3 and $49.2 \%$ for non-saline and saline soils, respectively. Direct 442measurements of DP confirmed these estimations by recording a DP $\quad \mathrm{f}$ of about $638.9 \mathrm{~mm}^{-}$year $^{-}$ 4431 . This is in accordance with high values of root zone moisture, which almost exceed the soil 444moisture at field capacity. The evolution of DP across the phenological phases has given 445additional information on the higher value of DP losses of about $200 \mathrm{~mm}$ with DP $\quad$ R(I) of $35 \%$ 446recorded during the fruit growth stage.

447The FAO-56 simple approach was used to assess the appropriate irrigation amount in case of 448saline and non-saline soils. The results shows that, by taking into account the rainfall, this 449model recommends an amount of irrigation much lower than that actually applied by the 450farmers. Following the model simulations, it seems possible to save about $39 \%$ of water 451 supply at the Saada site, with non-saline soil, and about $30 \%$ to $47 \%$ at the Agafay site, with 452saline soil. This study has demonstrated that a reasonable drip irrigation scheduling is 453necessary for water saving.

454As a main perspective of the study, the evaluation of DP losses would be important 455information to estimate groundwater recharge beneath the irrigated fields. However, regarding 456the heterogeneous lithology of the Haouz plain and its deep groundwater, the DP contribution 457to the aquifer recharge remains an important scientific issue. 
458Acknowledgments: This research was conducted within the International Joint Laboratory 459TREMA ( http://trema.ucam.ac.ma) and GEOHYD laboratory (Cadi Ayyad University). 460Funding were provided by SAGESSE (PPR program funded by the Moroccan Ministry of 461Higher Education), ANR AMETHYST project (ANR-12-TMED-0006-01), H2020 REC 462project (645642) financed by the Marie Skłodowska-Curie Research and Innovation Staff 463 Exchange (RISE). The first author was awarded mobility researcher training from the PHC 464Maghreb 32592VE/14MAG22. Thanks also to Moroccan CNRST for awarding a PhD 465scholarship to H. Nassah. We thank the farmers for their collaboration.

\section{References}

467Allen, R. G., Howell, T. A., Pruitt, W. O., Walter, I. A., \& Jensen M. E. (1991). Lysimeters 468for Evapotranspiration and Environmental Measurements: Proceedings of the 469International Symposium on Lysimetry. American Society of Civil Engineers (p. 456). 470New York, NY.

471Allen, R. G., Pereira, L. S., Raes, D., \& Smith M. (1998). Crop evapotranspiration: guidelines 472for computing crop water requirements. FAO Irrigation and Drainage (p. 56).

473Allen, R. G., Pereira, L. S., Howell, T. R., \& Jensen M. E. (2011). Evapotranspiration 474information reporting: Factors governing measurement accuracy. Agricultural Water 475 Management, 98 (6), 899-920.

476Allman, M., Jankovský, M., Allmanová, Z., \& Messingerová V. (2015). Comparison of the 477gravimetric sampling and impedance methods for measuring soil moisture content.

478Journal homepage, 62, 14-25.

479Ayars, J. E., Corwin, D. L., \& Hoffman G. J. (2012). Leaching and root zone salinity control. 480ASCE Manual and Report Engineering Practice No. 71. Agricultural Salinity 481Assessment and Management, 12, 371-403.

482Ayers, R. S., \& Westcot D. W. (1985). Water Quality for Agriculture. FAO Irrigation and 483Drainage (p. 174).

484Barnard, J. H., Van Rensburg, L. D., \& Bennie A. T. P. (2010). Leaching irrigation saline 485sandy to sandy loam apedal soils with water of a constant salinity.

Irrigation Science, 28 486(2), 191-201.

487Belaqziz, S., Mangiarotti, S., Le Page, M., Khabba, S., Er-Raki, S., Agouti, T., Drapeau, L., 488Kharrou, M. H., El Adnani, M., \& Jarlan L. (2014). Irrigation scheduling of a classical 489gravity network based on the Covariance Matrix Adaptation-Evolutionary Strategy 490algorithm. Comput. Electron. Agricultural Water Management, 102, 64-72. 
491Bellvert, J., Marsal, J., Girona, J., Gonzalez-Dugo, V., Fereres, E., Ustin, S. L., \& Zarco492Tejada P. J. (2016). Airborne thermal imagery to detect the seasonal evolution of crop 493water status in peach, nectarine and saturn peach orchards. Remote Sensing, 8, 1-17.

494Boman, B .J. (2002). Efficiency, uniformity and system evaluation. In: B.J. Boman, (ed.), 495Water and citrus: Use, regulation, systems, and management (pp. 399-414). Florida: E496Publishing in Food Agr Sci.

497Bos, M. G., Burton, M. A., \& Molden D. J. 2005. Irrigation and Drainage Performance 498Assessement: Practical Guidelines (p. 155). Trowbridge, US : CABI Publishing. 499Bouazzama, B., \& Bahri A. (2008). Effet du régime d'irrigation sur les paramètres de 500 production de la variété d'agrumes «Maroc late» au niveau du périmètre irrigué du 501Tadla. Homme, Terre et Eaux, 136, 37- 40.

502Boubker, J. (2004). La certification des agrumes au Maroc. CIHEAM-IAMB, Options 503Méditerranéennes, Série B/021-Proceedings of the Mediterranean Network on 504Certification of Citrus.

505Boukhari, K., Fakir, Y., Stigter, T. Y., Hajhouji, Y., \& Boulet G. (2015). Origin of recharge 506and salinity and their role on management issues of a large alluvial aquifer system in the 507semi-arid Haouz plain, Morocco. Environmental Earth Sciences, 73 (10), 6195-6212. 508Chehbouni, A., Escadafal, R., Duchemin, B., Boulet, G., Simonneaux, V., Dedieu, 509G.,Mougenot, B., Khabba, S., Kharrou, H., Maisongrande, P., Merlin, O., Chapon510nière, A., Ezzahar, J., Er-Raki, S., Hoedjes, J., Hadria, R., Abourida, A., Cheggour, A., 511Raibi, F., Boudhar, A., Benhadj, I., Hanich, L., Benkaddour, A., Guemouria, N 512Chehbouni, A. H., Lahrouni, A., Olioso, A., Jacob, F., Williams, D. G., \& Sobrino J. 513(2008). An integrated modeling and remote sensing approach for hydrological study in 514arid and semi-arid regions: the SUDMED Programme. International Journal of Remote 515Sensing, 29 (17-18), 5161-5181.

516Constantz, J., Tyler, W., \& Kwicklis E. (2003). Temperature-profile methods for estimating 517percolation rates in arid environments. Vadose Zone Journal, 2, 12-24.

518Deurer, M., Clothier, B. E., Green, S. R., \& Gee G., (2008). Infiltration rate, hydraulic 519conductivity and preferential flow. In: S. D. Logsdon, D. Clay, D. Moore, \& T. Tsegaye 520(Eds.), Soil Science: Step-by-step Field Analyses (pp. 221-233). USA: Soil Science 521Society of America.

522Domingo, J. I., Manuel, C., José, M. C., Miguel, A. N., Gabino, R., Esther, C., Omar, R., 523Ignacio, L., Raphael, M., Francisco, R., Tadeo, \& Manuel T. (2007). Physiology of 524citrus fruiting. Plant Physiology, 19 (4), 333-362. 
525Duncan, M. J., Srinivasan, M. S., \& Mc Millan H. (2016). Field measurement of groundwater 526recharge under irrigation in Canterbury, New Zealand, using drainage lysimeters.

527Agricultural Water Management, 166, 17-32.

528El Hari, A. (1992). Besoins en eau des agrumes dans le Haouz-Effet du stress hydrique sur le 529rendement et le calibre du clémentinier. Diplôme d'Etudes Supérieures (DES), Faculté 530des Sciences. Université Cadi Ayyad. Marrakech, Maroc.

531El Hari, A., Chaik, M., Lekouch, N., \& Sedki A. (2010). Water needs in citrus fruit in a dry 532region of Morocco. Agriculture and Environment for International Development, 104 (3 533-4), 91- 99.

534Er-Raki, S., Chehbouni, A., Guemouria, N., Ezzahar, J., Khabba, S., Boulet, G., \& Hanich L. 535(2009). Citrus orchard evapotranspiration: Comparison between eddy covariance 536measurements and the FAO-56 approach estimates. Plant Biosystems, 143 (1), 201-208. 537Er-Raki, S., Khabba, S., Erraji, T., Ezzahar, J., Jarlan. L., Hanich. L., \& Chehbouni A. (2012). 538Evaluation of the sap flow measurements determined with heat balance method for 539 citrus orchards in semi-arid region. Acta Horticulturae, 951, 259-268.

540Er-Raki, S., Ezzahar, J., Khabba, S., Jarlan, L., Kharrou, M. H., \& Chehbouni G. (2013). 541Micrometeorology Tools for Measuring Evapotranspiration from the Leaf to the 542Region. In: S. Er-Raki (Eds.), Evapotranspiration: Processes, Sources and 543Environmental Implications (pp. 1-22). Nova Publishers, ISBN: 978-1-62417-138-3.

544Ezzahar, J., Chehbouni, A., Hoedjes, J., Er-Raki, S., Chehbouni, A.h., \& Bonnefond J.M. 545(2007). The use of the Scintillation Technique for estimating and monitoring water 546consumption of olive orchards in a semi-arid region. Agricultural Water Management, $54789,173-184$.

548FAO. (2003). FAO Statistics. Available: http:/apps.fao.org/default.htm.

549García, M. P., \& Castel J. R. (2007). Water balance and crop coefficient estimation of a citrus 550orchard in Uruguay. Spanish Journal of Agricultural Research, 5 (2), 232-243.

551Gee, G. W., Newman, B. D., Green, S. R., Meissner, R., Rupp, H., Zhang, Z. F., Keller, J. M., 552Waugh, W. J., van der Velde, M., \& Salazar J. (2009). Passive wick fluxmeters: Design 553considerations and field applications. Water Resources Research, 45, 1-18.

554Käthner, J., Ben-Gal, A., Gebbers, R., Peeters, A., Herppich, W. B., \& Zude-Sasse M. (2017). 555Evaluating Spatially Resolved Influence of Soil and Tree Water Status on Quality of 556European Plum Grown in Semi-humid Climate. Front. Plant Sci, 8:1053.

557Kelly, T. M., $\quad$ Lincoln, Z., \& Michael D. D. (2010). Use of Irrigation Technologies for Citrus 558Trees in Florida. Horl Technology, 20 (1), 75-81. 
559Khabba, S., Jarlan, L., Er-Raki, S., Le Page, M., Ezzahar, J., Boulet, G., Simonneaux, 560V., Kharrou, M. H., Hanich L., \& Chehbouni G. (2013). The SudMed program and the 561joint international laboratory TREMA: A decade of water transfer study in the soil-562plantatmosphere system over irrigated crops in semi-arid area. Procedia Environmental 563sciences, $19,524-533$.

564Kharrou, M. H., Er-Raki, S., Chehbouni, A., Duchemin, B., Simonneaux, V., Le Page, M., 565Ouzine, L., \& Jarlan L. (2011). Water use efficiency and yield of winter wheat under 566different irrigation regimes in a semi-arid region. Agricultural Sciences, 2, 273-282.

567Kharrou, M. H., Le Page, M., Chehbouni, A., Simonneaux, V., Er-Raki, S., Simonneaux, V., 568Jarlan, L., \& Ouzine L. (2013). Assessment of equity and adequacy of water delivery in 569irrigation systems using remote sensing-based indicators in semi-arid region, Morocco. 570 Water Resources Management, 27 (13), 4697-4714.

571Kim, Y., Jabro, J. D., \& Evans R. G. (2011). Wireless lysimeters for real-time online soil 572water monitoring. Irrigation Science, 29 (5), 423-430.

573Lado, J., Rodrigo, M. J., \& Zcarias L. (2014). Maturity indicators and citrus fruit quality. $574 \quad$ Stewart Postharvest Review, 10 (2), 1-6.

575Landon, J. S. H., Hamid, R., Gabriel C. R., \& Martin S. A. (2016). Calculating water 576saturation from passive temperature measurements in near-surface sediments: 577Development of a semi-analytical model. Water Resources, 89, 67-79.

578Le Page, M., Berjamy, B., Fakir, Y., Bourgin, F., Jarlan, L., Abourida, A., Benhanem, M., 579Jacob, G., Huber, M., Sghrer, F., Simonneaux, V., \& Chehbouni G. (2012). An 580integrated DSS for groundwater management based on remote sensing: The case of a 581semi-arid aquifer in Morocco. Water Resources Management, 26 (11), 3209-3230. 582MAPM. (2013). Ministère de l'Agriculture et de la Pêche Maritime, Note de veille secteur 583agrumicole. Note stratégique $\mathrm{n}^{\circ} 97,19 \mathrm{p}$.

584Mathieu, C., \& Pieltain F. (2003). Analyse chimique des sols. Ed. Tec et doc. Lavoisier, Paris, $585292 \mathrm{p}$.

586Naidu, R., Kookuna, R. S., Olivier, D. P., Rogers, S., \& Mclaughlin M. J. (1996). 587Contaminants and the soil environment in the australasia Pacific Region. Kluwer 588Academic Publishers, 721p.

589Plaut, Z., Edelstein, M., \& Ben-Hur M. (2013). Overcoming Salinity Barriers to Crop 590Production Using Traditional Methods. Plant Sciences, 32 (4), 250-291. 591PMV. (2013). Plan Maroc Vert: Région de Marrakech Tensift Al Haouz. Rabat 
592Qinbo, C., Chen, Xi., Xunhong, C., Zhicai, Z., \& Minhua L. (2011). Water infiltration 593underneath single-ring permeameters and hydraulic conductivity determination. Journal 594of Hydrology, 398 (1-2), 135-143.

595Richards, L. A. (1954). Diagnosis and improvement of Saline alkali soils. Soil and Water 596Conservation Research Branch. Agriculture H and book No. 60.

597Robert, H., \& Richard T. K. (1999). Water salinity and crop yield. Working paper (AG598425.3), Utah State University, Logan, UT 84322, United States, December.

599Roerink, G. J., Bastiaanssen, W. G. M., Chambouleyron, J., \& Menenti M. (1997). Relating 600 crop water consumption to irrigation water supply by remote sensing.

Water Resources 601 Management, 11 (6), 445-465.

602Rosa, R.D., Ramos, T.B., \& Pereira L.S. (2016). The dual Kc approach to assess maize and 603sweet sorghum transpiration and soil evaporation under saline conditions: Application 604of the SIMDualKc model. Agricultural Water Management, 177, 77-94.

605Russo, D., Laufer, A., Silber, A., \& Assouline S. (2009). Water uptake, active root volume, 606and solute leaching under drip irrigation: A numerical study. Water Resources 607Research, 45 (12), 1-19.

608Sammis, T. W., Evans, D. D., \& Warrick A. W. (1983). Comparison of methods to estimate 609deep percolation rates. Water Resources Bulletin, 18 (3), 465-470.

610Sefiani, S., El Mandour, A., Laftouhi, N., Khalil, N., Kamal, S., Jarlan, L., Chehbouni, A., 611Hanich, L., Khabba, S., \& Addi A. (2017). Assessment of soil quality for a semi-arid 612irrigated under citrus orchard; case of the Haouz plain, Morocco. European Scientific 613Journal, 13 (6), 367-388.

614Sheng, L. Y., Tomohisa, Y., Mehmet, A., Yoshinobu, K., \& Shin-ichi T. (2002). Short term 615 effects of saline irrigation on evapotranspiration from lysimeter-grown citrus trees. 616Agricultural Water Management, 56, 131-141.

617Stephens, D. B., Moore, S., Cartron, D., \& Blandford T. N. (2006). Quantifying return flow to 618groundwater: Presentation at the National Ground Water Association. 61p.

619Stonestrom, D. A., Prudic, D. E., Laczniak, R. J., Akstin, K. C., Boyd, R. A., \& Henkelman 620K.K. (2003). Estimates of deep percolation beneath irrigated fields, native vegetation,

621and the Amargosa River channel, Amargosa Desert, Nye County, Nevada: U.S. 622 Geological Survey Open-File Report 03-104, 83 p.

623Troy, R. P., Kefyalew, D., \& Leigh N. (2013). Practical Use of Soil Moisture Sensors and 624Their Data for Irrigation Scheduling. Washington State University. 
625Upreti, H., Ojha, C. S. P., \& Hari P. K. S. (2015). Estimation of Deep Percolation in Sandy626Loam Soil using Water balance Approach. Irrigation Drainage Systems Engineering. 627Vázquez, N., Pardo, A., Suso, M. L., \& Quemada M. (2006). Drainage and nitrate leaching 628under processing tomato growth with drip irrigation and plastic mulching.

Agriculture 629 Ecosystems and Environment, 112 (4), 313-323.

630Visconti, F., de Paz, J. M., Rubio, J. L., \& Sánchez J. (2012). Comparison of four steady-state 631 models of increasing complexity for assessing the leaching requirement in agricultural 632salt-threatened soils. Agricultural Research, 10 (1), 222-237. 633Wang, P., Song, X. F., Han, D. M., Zhang, Y. H., \& Zhang B. (2012). Determination of 634evaporation, transpiration and deep percolation of summer corn and winter wheat after 635irrigation. Agricultural Water Management, 105, 32-37.

636Wosten, J. H. M., Finke, P. A., \& Jansen M. J. W. (1995). Comparison of class and 637 continuous pedotransfer functions to generate soil hydraulic characteristics. Geoderma, $63866(3-4), 227-237$.

639Li, X., Jin, M., Zhou, N., Huang, J., Jiang, S., \& Telesphore, H. (2016). Evaluation of 640evapotranspiration and deep percolation under mulched drip irrigation in an oasis of 641Tarim basin, China. Journal of Hydrology, 677-688.

642Levy, Y., \& Syvertsen, J. (2004). Irrigation Water Quality and Salinity Effects in Citrus 643Trees. Horticultural Reviews, 30, 38-71. 


\section{Figure captions}

Figure 1: Location of the study sites Agafay and Saada.

Figure 2: Daily reference evapotranspiration (dotted line: $\mathrm{ET}_{0}$ ) calculated following the FAOPenman-Monteith equation and precipitation events (vertical bars : P) in the study orchards: Agafay during 2007 (a), 2010 (b) and Saada during 2004 (c).

Figure 3: Cumulative deep percolation measured by fluxmeter (solid line: $\mathrm{DP}_{\mathrm{f}}$ ) and deep percolation calculated by water balance (dashed line: DP) in Agafay for 2010.

Figure 4: Daily rainfall (vertical bars: P), deep percolation (dashed line: DP) and soil moisture (continous line: $\square_{\square}$ ) for bare soil in depth $60-80 \mathrm{~cm}$ (example of Agafay site, 2007). The upper and the lower horizontal continuous lines corresponds to the soil moisture at field capacity ( $\square_{\square \square}$ ) and at wilting

point $\left(\square_{\square \square}\right)$, respectively. The areas of soil moisture variation above $\theta_{\mathrm{fe}}$ between $\theta_{\mathrm{fc}}$ and $\theta_{\mathrm{wp}}$ and below $\theta_{\text {wp }}$ correspond to the deep percolation, available soil water and unavailable soil water zones, respectively.

Figure 5: Daily water supply (vertical bars: I+P), deep percolation (dashed line: DP) and soil moisture (continous line: $\square_{\square}$ ) for irrigated part in depth $60-80 \mathrm{~cm}$ (example of Agafay site, 2010). The upper and the lower horizontal continuous lines corresponds to the soil moisture at field capacity $\left(\square_{\square \square}\right.$ ) and at wilting point $\left(\square_{\square \square}\right)$, respectively. The areas of soil moisture variation above $\theta_{\mathrm{fc}}$, between $\theta_{\mathrm{fc}}$ and $\theta_{\mathrm{wp}}$ and below $\theta_{\mathrm{wp}}$ correspond to the deep percolation, available soil water and unavailable soil water zones, respectively.

Figure 6: Variation of deep percolation (dashed line: DP), actual crop evapotranspiration (- $\square$ ETc_act) and irrigation (vertical bars: I) according to the phenological stages during 2007 in Agafay.

Figure 7: Relative deep percolation evolution according to the phenological stages during (grey vertical bars : 2007 ) and (white vertical bars: 2010) in Agafay and (black vertical bars: 2004) in Saada.

Figure 8: Combined analysis of relative evapotranspiration (RET) and depleted fraction (DF) for all phenological phases: ( $\downarrow$ : induction), ( $\square$ : flowering), ( $\square$ : Fruit set), ( $\square$ : Fruit drop), (○: growth), ( $\square$ : slowdown growth), ( $\square$ : maturation) and ( $\square$ : harvest) for Agafay (2007: (a)), (2010: \and Saada in (2004: (c)).

Figure 9: Weekly evolution of precipitation (black vertical bars: P ), irrigation (grey vertical bars: I ), actual crop evapotranspiration ( $\square$ : ETc_act ) and deep percolation (dashed line: DP ) during $200 \%$ : (a)) and (2010: (b)) in Agafay.

Figure 10: Effect of the variation of soil electric conductivity (Ece) on the total stress coefficient (dashed line: Kstot). The required irrigation for each value of Ece is also shown ( $\square$ ). The horizontal continuous line correpsonds to the amount of recommended irrigation without salinity issue. 


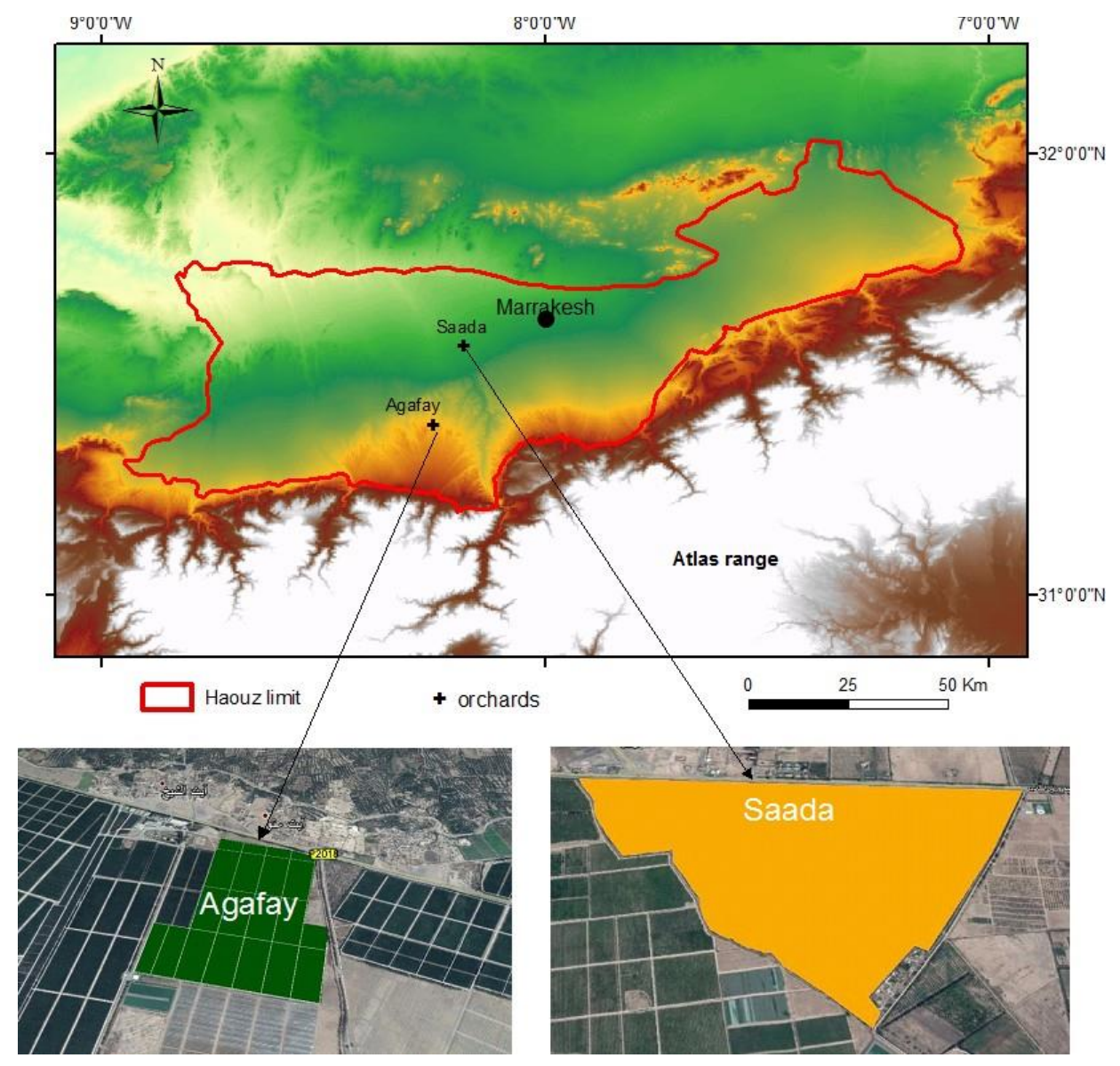

Figure 1 


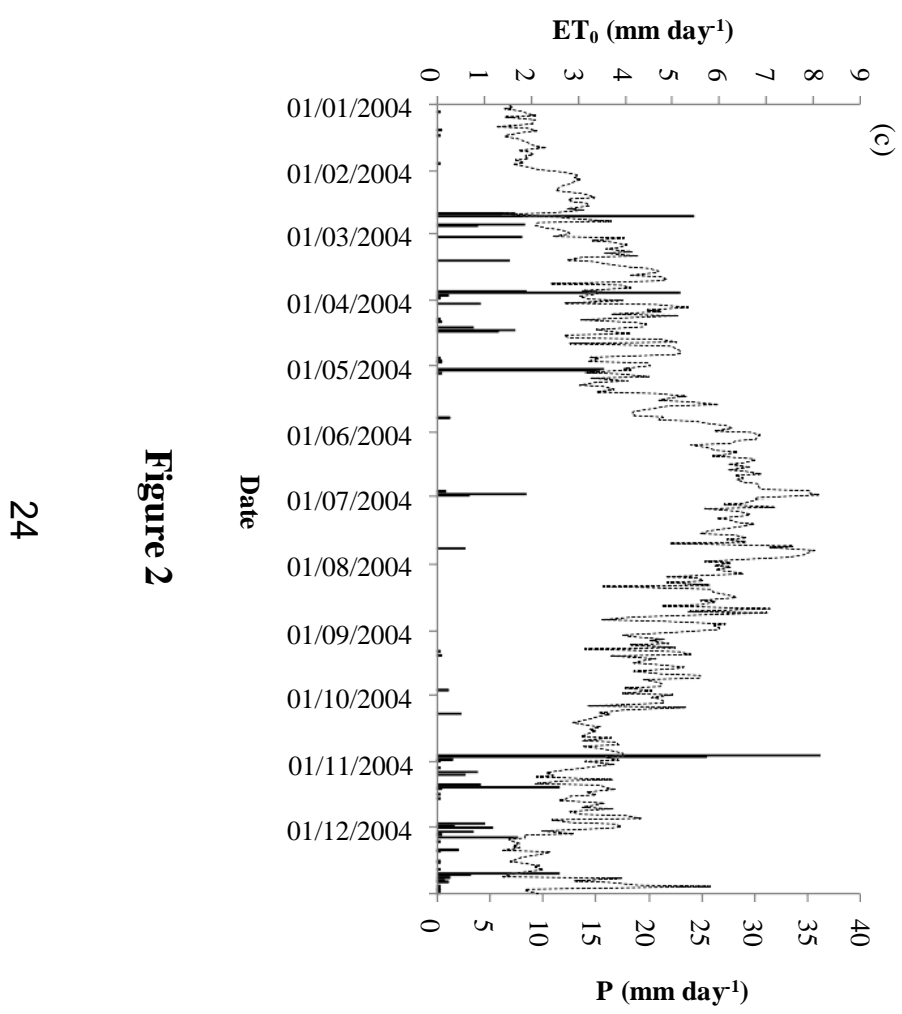

$\mathrm{ET}_{\mathbf{0}}\left(\mathrm{mm} \mathrm{day}{ }^{-1}\right)$

$\mathrm{ET}_{0}\left(\mathrm{~mm} \mathrm{day} \mathbf{y}^{-1}\right)$
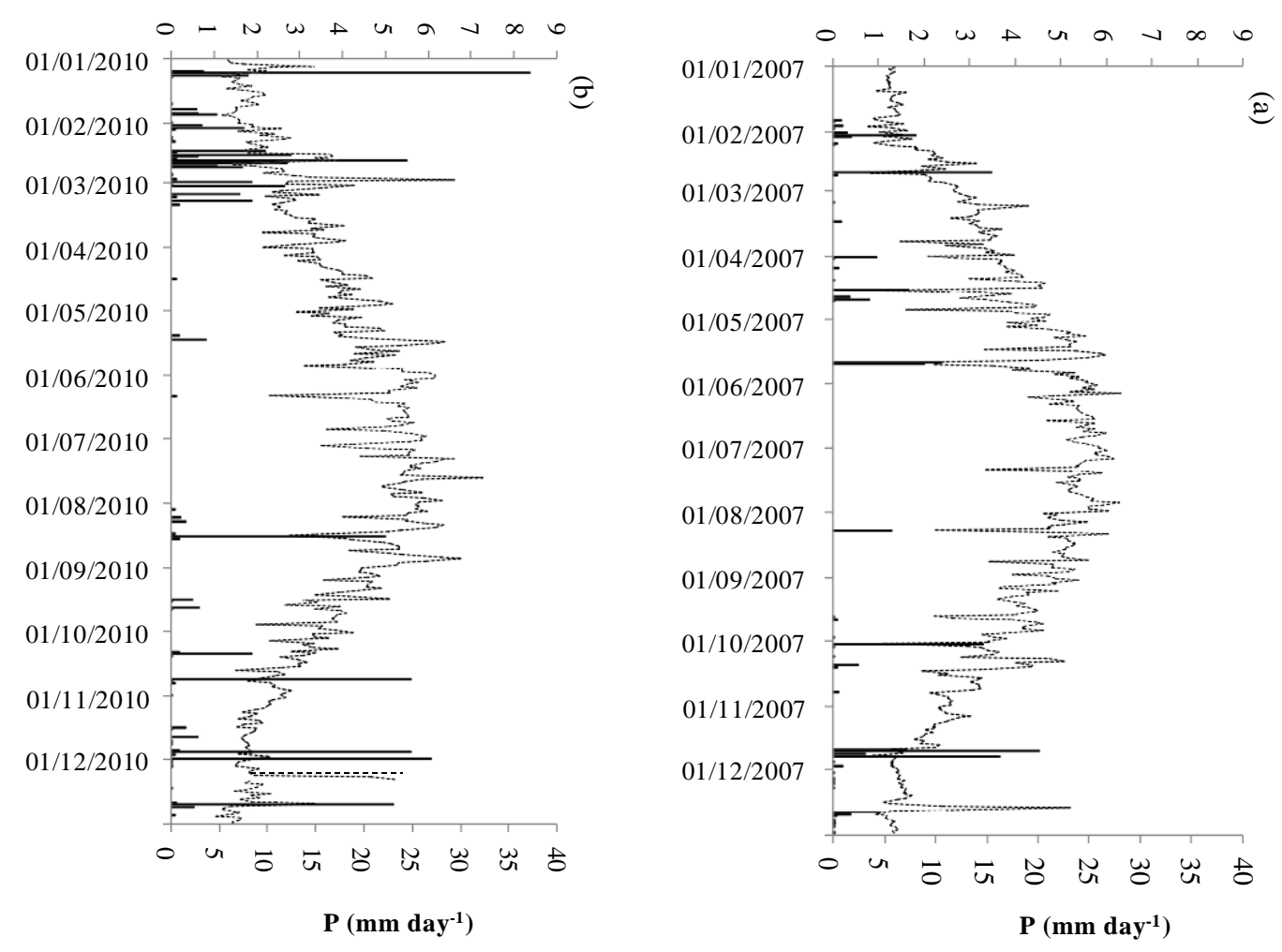


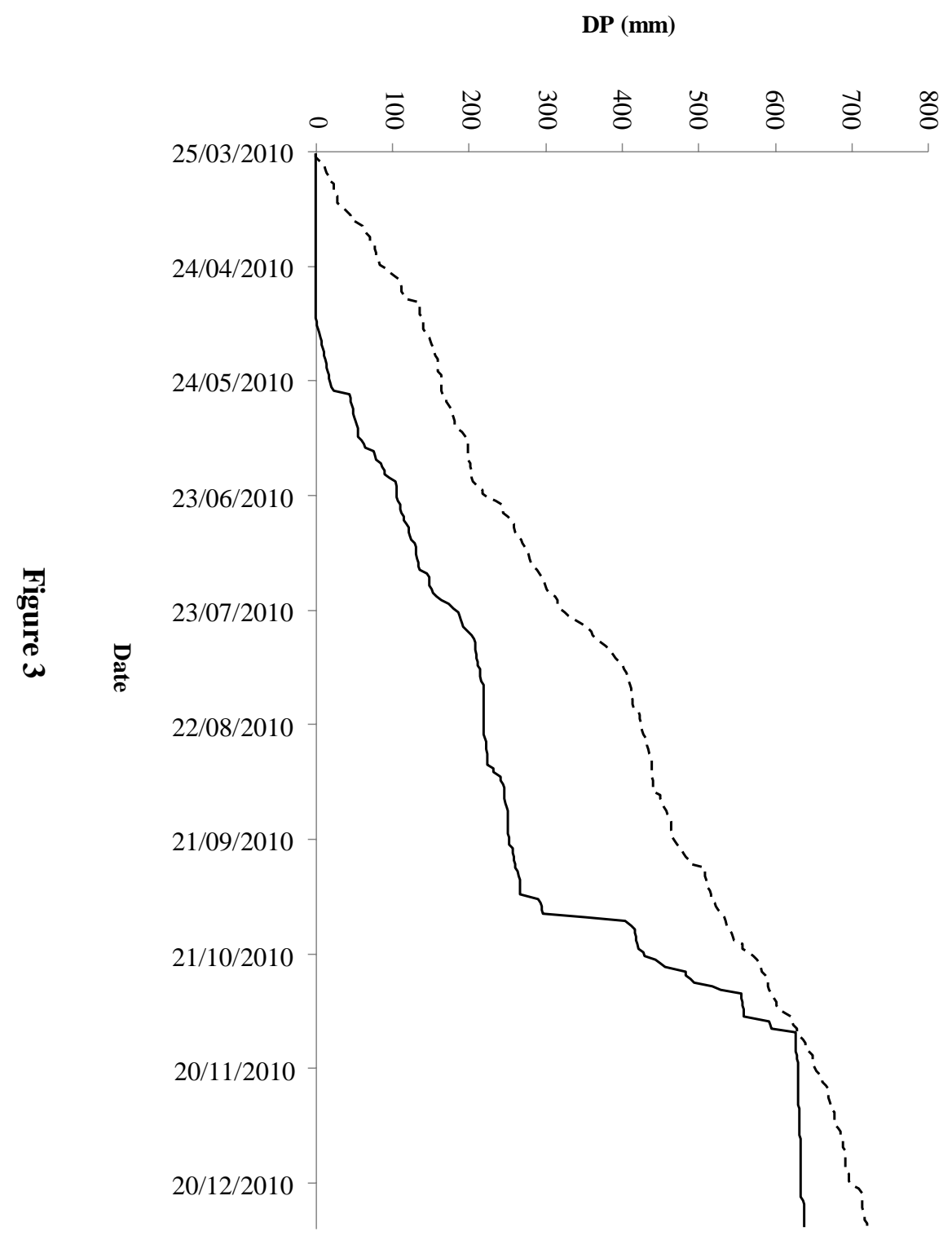




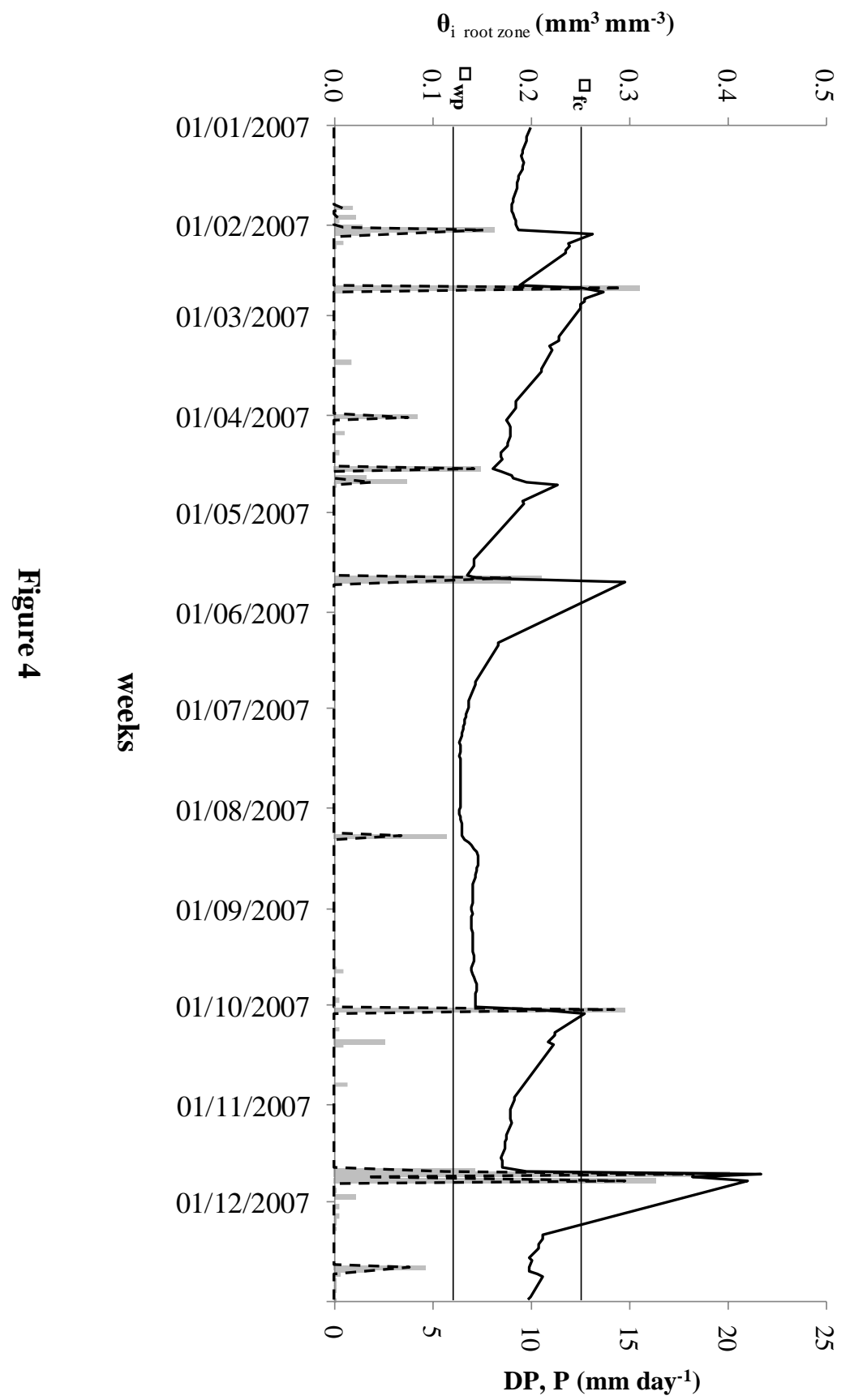




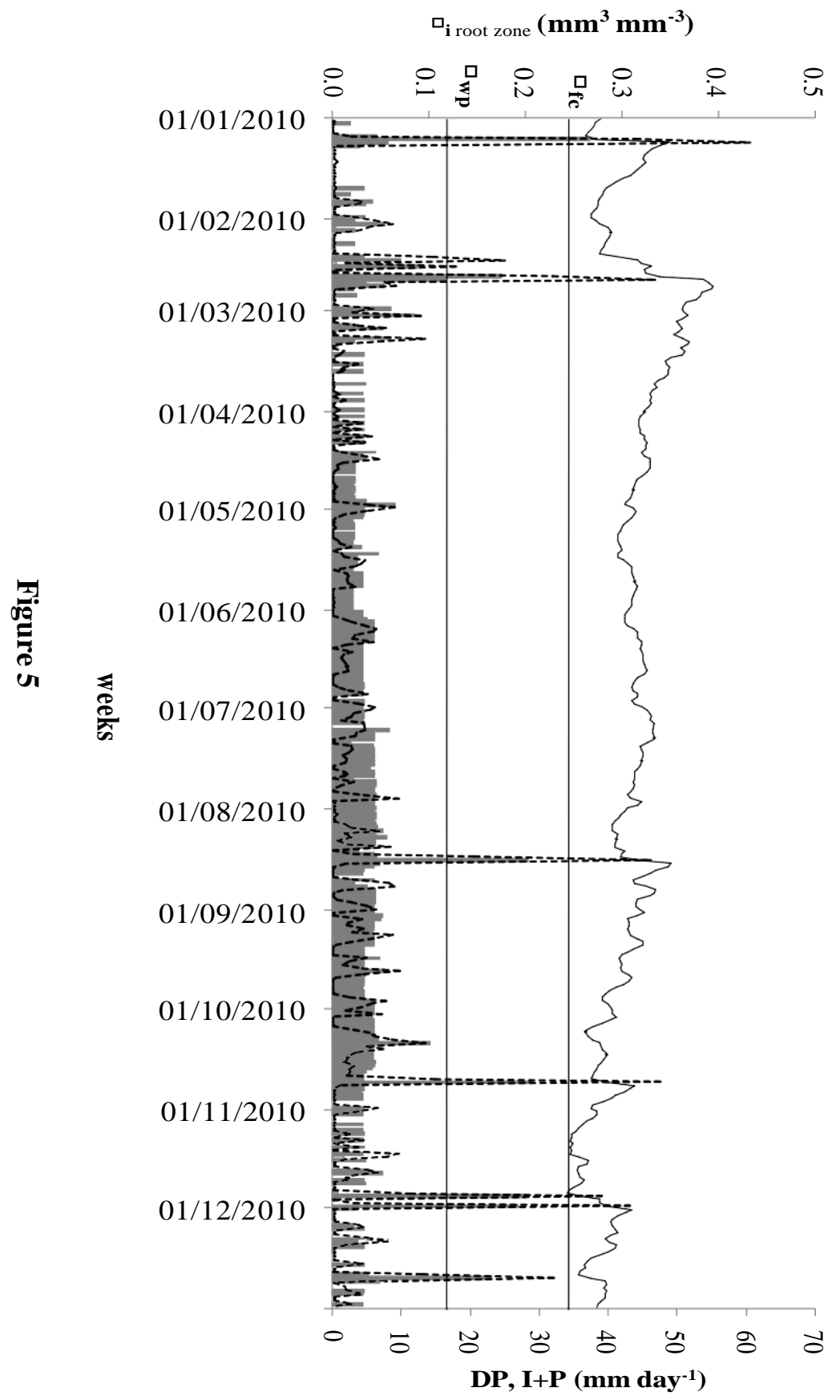




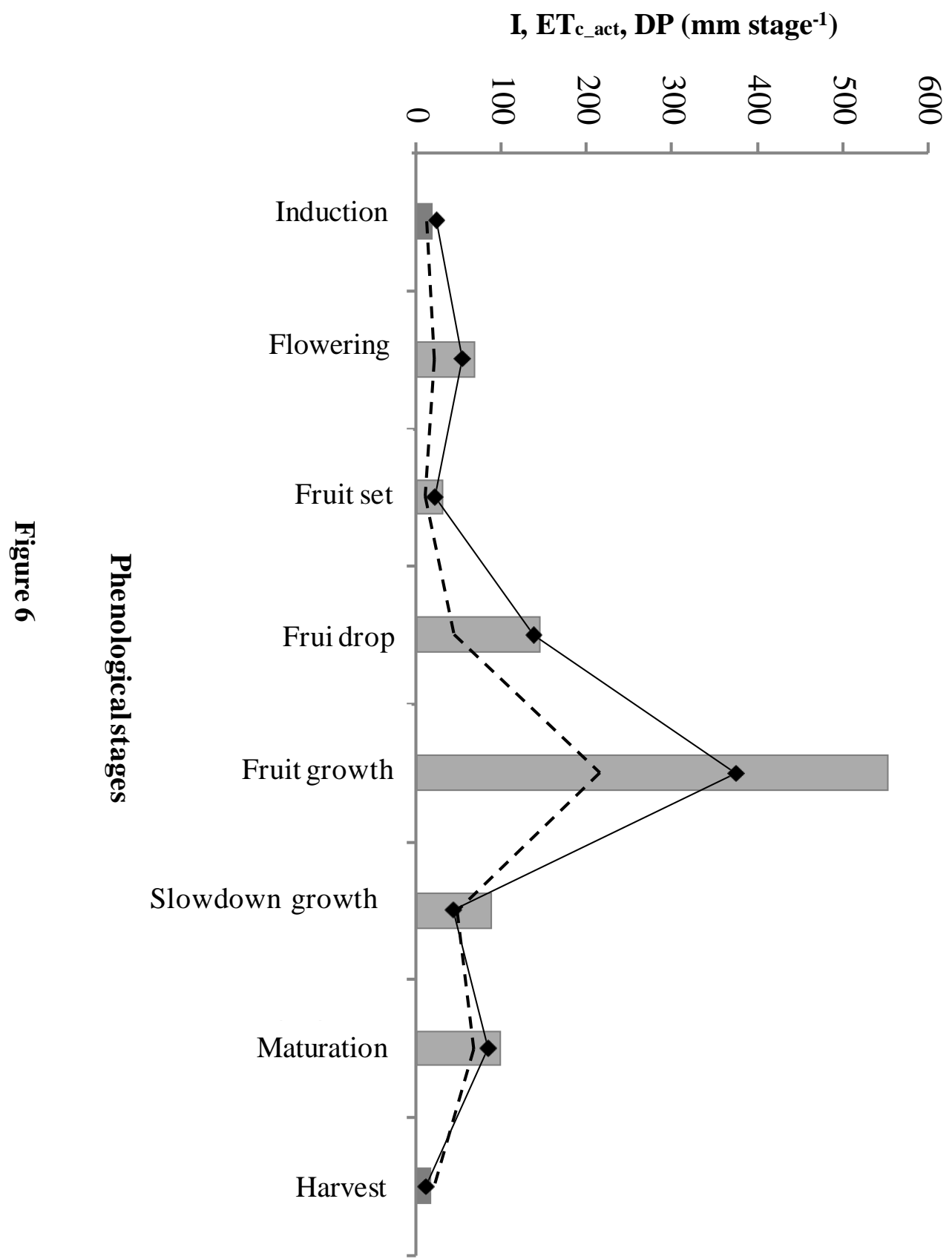




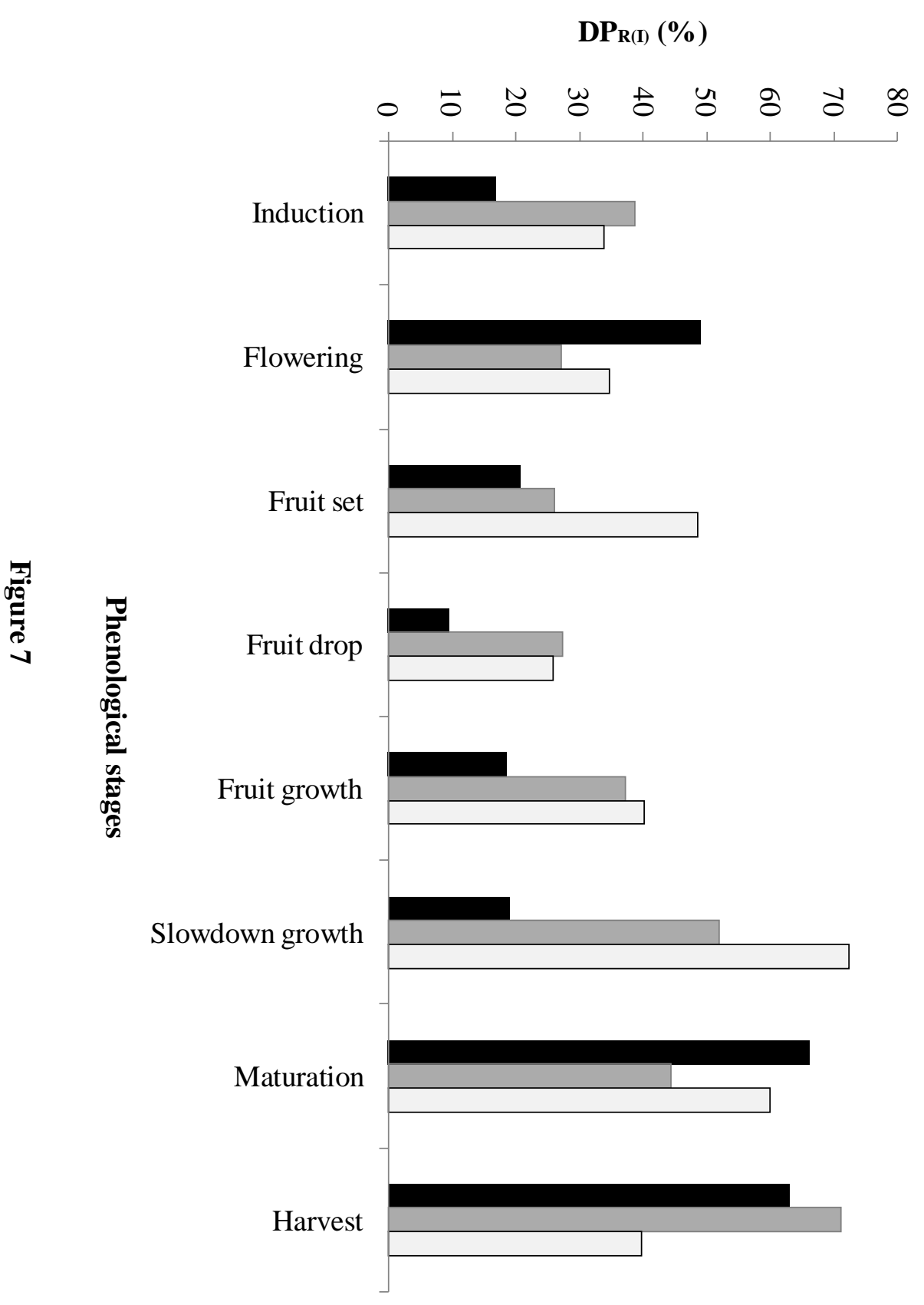


(a)

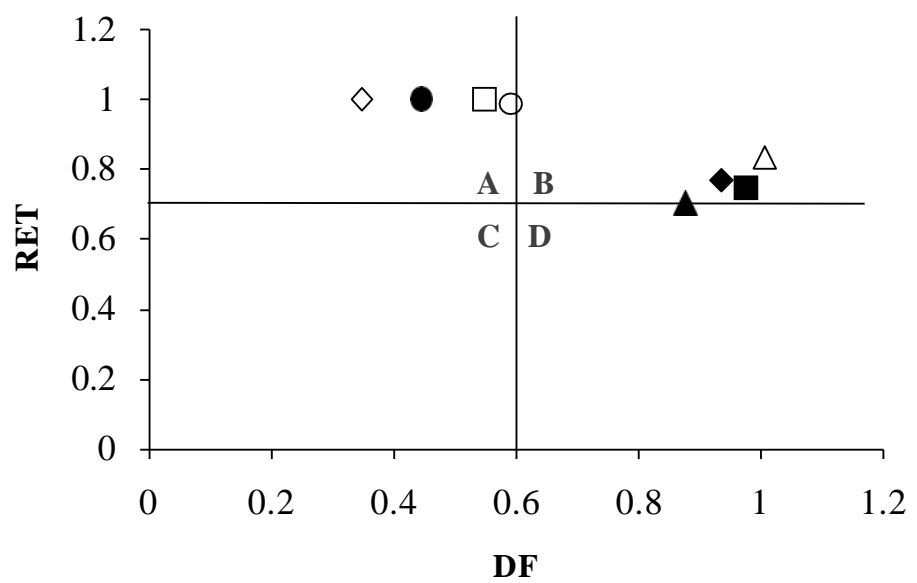

(b)

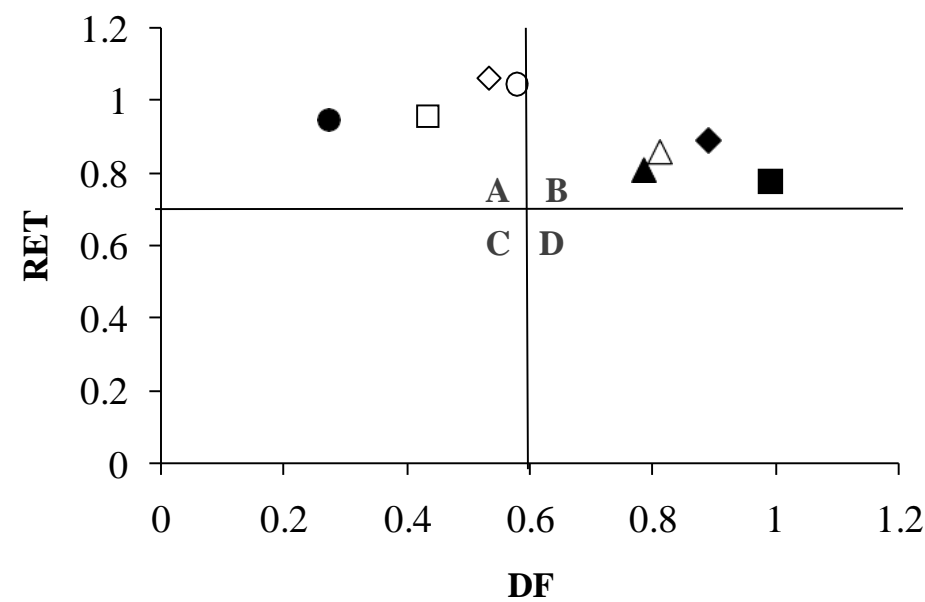

(c)

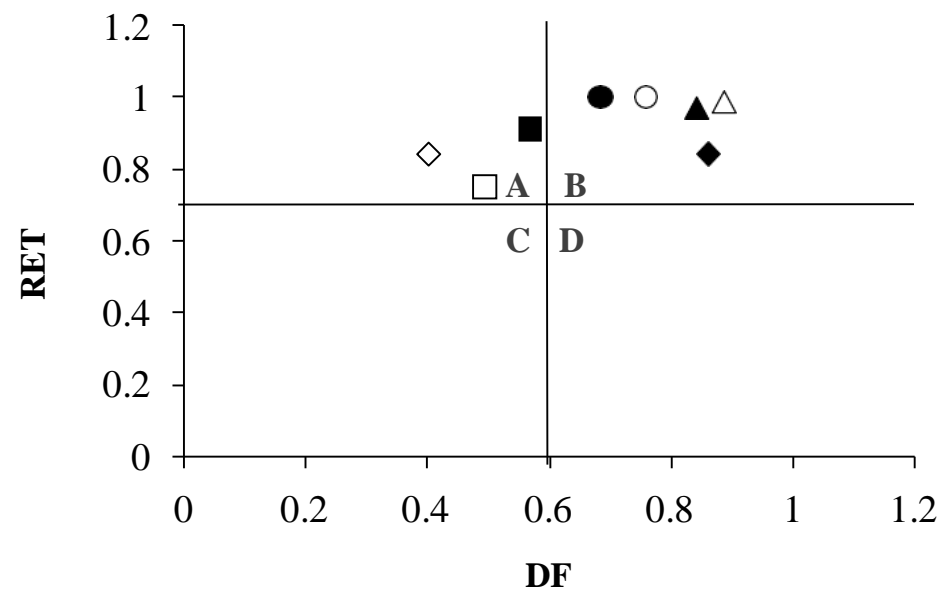

Figure 8 

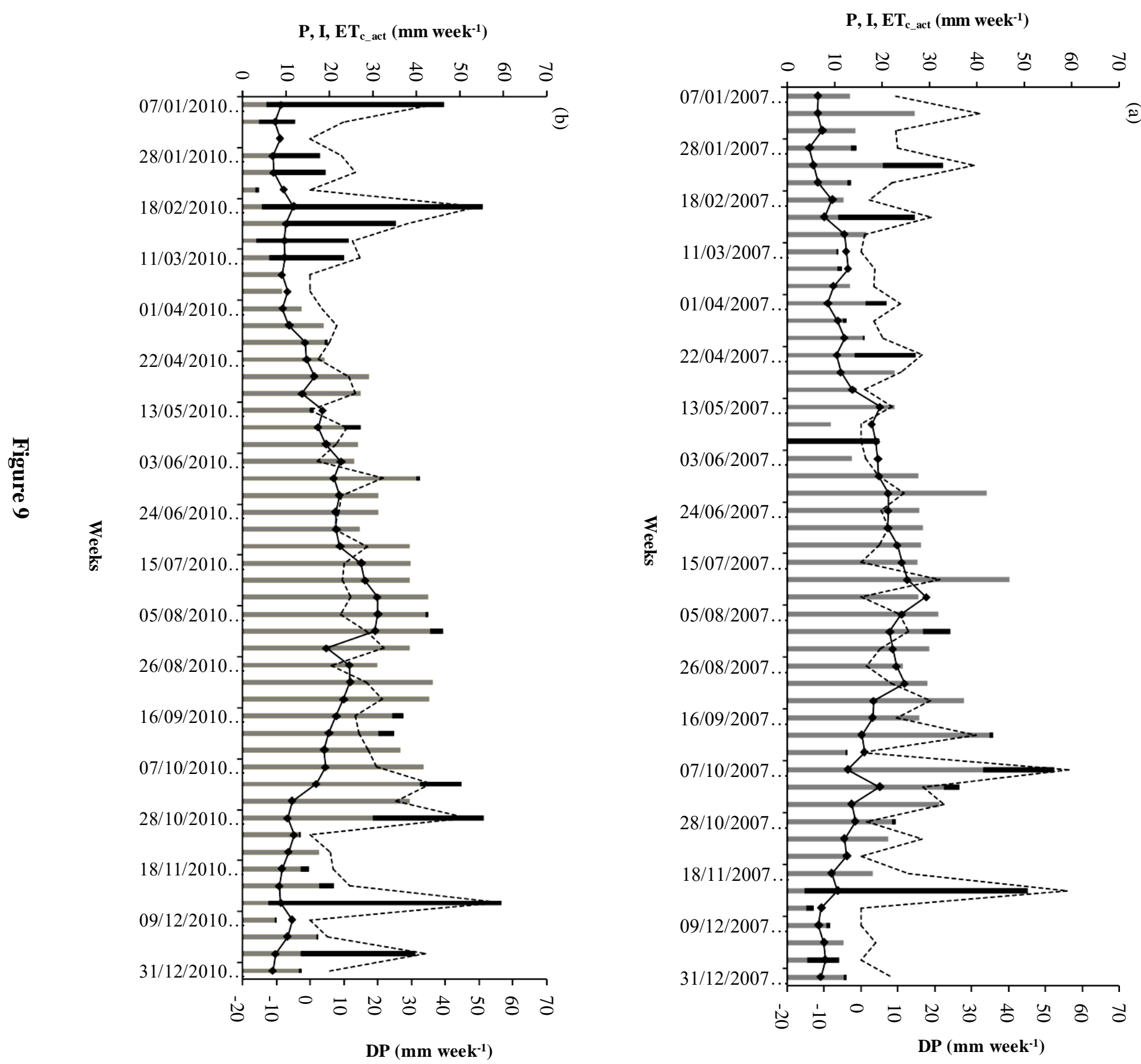


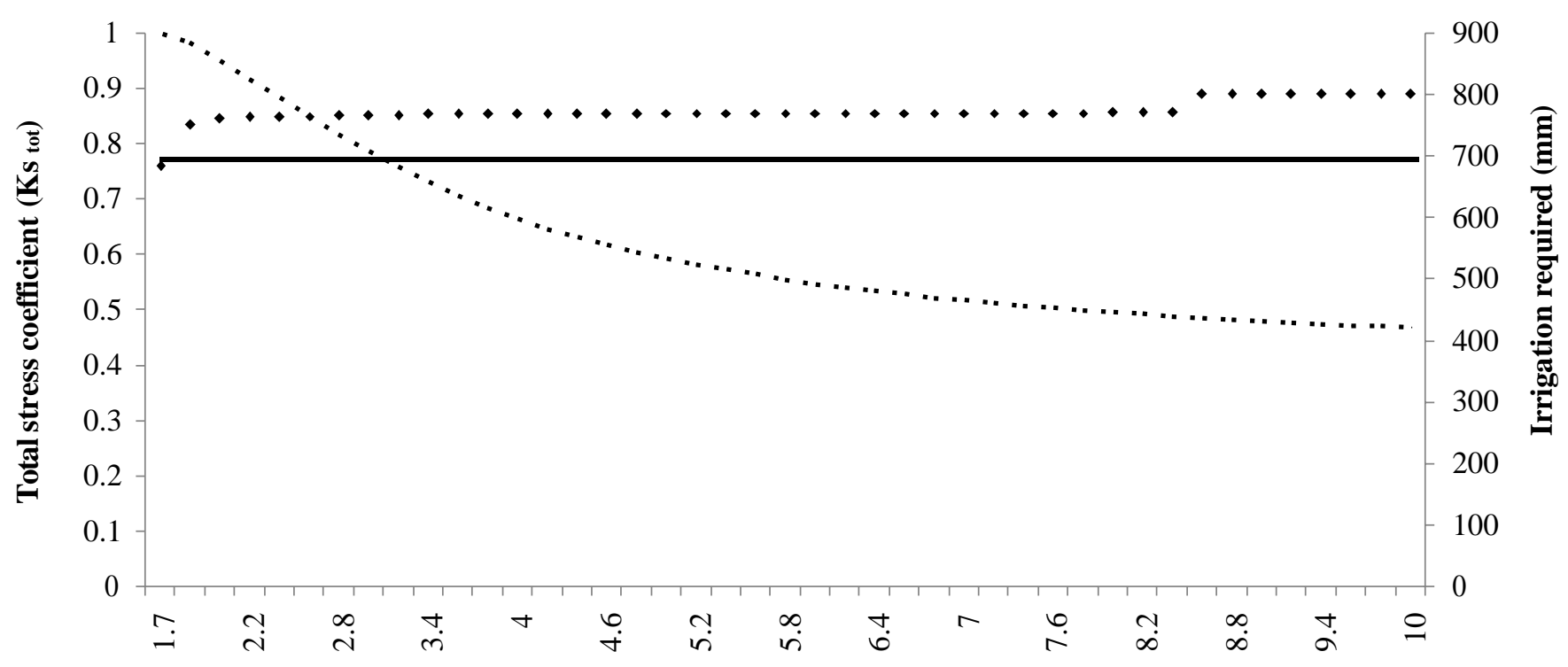

Electric conductivity Ece (dS m $\left.\mathbf{m}^{-1}\right)$

Figure 10 
Table 1: Annual values of actual crop evapotranspiration $\left(\mathbf{E T}_{\mathbf{c} \_ \text {act }}\right)$, rainfall $(\mathbf{P})$, Irrigation (I), deep percolation (DP) and relative deep percolation $\left(D P_{R}\right)$ in non-saline (Saada) and saline soil (Agafay) sites.

\begin{tabular}{|c|c|c|c|c|c|c|}
\hline orchards & years & $\mathbf{E T}_{\mathbf{c} \_ \text {act }}(\mathbf{m m})$ & $\mathbf{P}(\mathbf{m m})$ & $\mathbf{I}(\mathbf{m m})$ & $\mathbf{D P}(\mathbf{m m})$ & $\mathbf{D P}_{\mathbf{R}(\mathbf{I}+\mathbf{P})}(\boldsymbol{\%})$ \\
\hline Saada & 2004 & 786.3 & 295.8 & 910.4 & 420.3 & 38.3 \\
\hline \multirow{2}{*}{ Agafay } & 2007 & 754.8 & 148.3 & 1061.3 & 454.8 & 49.3 \\
\cline { 2 - 7 } & 2010 & 818.1 & 342.6 & 1188.6 & 708.6 & 46.3 \\
\cline { 2 - 7 } & Average & 786.4 & 245.4 & 1124.9 & 581.7 & 47.8 \\
\hline \multicolumn{2}{|r|}{ Overall average } & 786.4 & 270.6 & 1017.7 & 501 & 43 \\
\hline
\end{tabular}

*DPR(P+I)(\%) is calculated in daily basis

Table 2: Seasonal values of irrigation (I), deep percolation (DP) and relative deep percolation (DPR) in non-saline (Saada) and saline soil (Agafay) orchards.

\begin{tabular}{|c|c|c|c|c|c|c|c|c|c|c|}
\hline \multirow{3}{*}{\multicolumn{2}{|c|}{$\begin{array}{c}\text { orchards } \\
\text { Years } \\
\text { Variables }\end{array}$}} & \multirow{2}{*}{\multicolumn{3}{|c|}{$\begin{array}{c}\text { Saada } \\
2004\end{array}$}} & \multicolumn{6}{|c|}{ Agafay } \\
\hline & & & & & \multicolumn{3}{|c|}{2007} & \multicolumn{3}{|c|}{2010} \\
\hline & & I (mm) & $\mathrm{DP}(\mathrm{mm})$ & $\operatorname{DP}_{R(I)}(\%)$ & I (mm) & $\mathrm{DP}(\mathrm{mm})$ & $\operatorname{DP}_{\mathrm{R}(\mathrm{I})}(\%)$ & I (mm) & $\mathrm{DP}(\mathrm{mm})$ & $\operatorname{DP}_{R(I)}(\%)$ \\
\hline \multirow[t]{2}{*}{ season } & wet & 365.7 & 279.8 & 46.1 & 394.5 & 216.7 & 41.9 & 388.2 & 355.5 & 53.4 \\
\hline & dry & 544.7 & 270.5 & 24.6 & 667.1 & 240 & 34.7 & 800.4 & 417.5 & 48.1 \\
\hline
\end{tabular}

Table 3: Weekly rates of irrigation (I), actual crop evapotranspiration (ET $\mathbf{E}_{-}$act), deep percolation (DP) and relative deep percolation $\left(D_{R}\right)$ in presence of precipitations in saline soil (Agafay).

\begin{tabular}{|c|c|c|c|c|c|}
\hline weeks & $\mathbf{P}(\mathbf{m m})$ & $\mathbf{I}(\mathbf{m m})$ & ET $_{\mathbf{c} \_ \text {act }}(\mathbf{m m})$ & DP $(\mathbf{m m})$ & DP $_{\mathbf{R}(\mathbf{I}+\mathbf{P})}(\mathbf{\%})$ \\
\hline $\mathbf{1 7 - 2 3 / 1 2 / 2 0 1 0}$ & 25 & 13.6 & 7.6 & 34.6 & 89 \\
\hline $\mathbf{2 1 - 2 7 / 1 2 / 2 0 0 7}$ & 6.8 & 8.6 & 6.7 & 12.8 & 83 \\
\hline
\end{tabular}

